IZA DP No. 1169

J ob Mobility along the Technological Ladder: A Case Study of Australia

Xin Meng

P. N. (Raj a) J unankar

Cezary A. Kapuscinski

J une 2004 


\title{
Job Mobility along the Technological Ladder: A Case Study of Australia
}

\author{
Xin Meng \\ Australian National University \\ P. N. (Raja) Junankar \\ University of Western Sydney \\ and IZA Bonn \\ Cezary A. Kapuscinski \\ Australian Government \\ Department of Education, Science and Training
}
Discussion Paper No. 1169
June 2004

\author{
IZA \\ P.O. Box 7240 \\ 53072 Bonn \\ Germany \\ Phone: +49-228-3894-0 \\ Fax: +49-228-3894-180 \\ Email: iza@iza.org
}

Any opinions expressed here are those of the author(s) and not those of the institute. Research disseminated by IZA may include views on policy, but the institute itself takes no institutional policy positions.

The Institute for the Study of Labor (IZA) in Bonn is a local and virtual international research center and a place of communication between science, politics and business. IZA is an independent nonprofit company supported by Deutsche Post World Net. The center is associated with the University of Bonn and offers a stimulating research environment through its research networks, research support, and visitors and doctoral programs. IZA engages in (i) original and internationally competitive research in all fields of labor economics, (ii) development of policy concepts, and (iii) dissemination of research results and concepts to the interested public.

IZA Discussion Papers often represent preliminary work and are circulated to encourage discussion. Citation of such a paper should account for its provisional character. A revised version may be available on the IZA website (www.iza.org) or directly from the author. 


\section{ABSTRACT \\ Job Mobility along the Technological Ladder: A Case Study of Australia*}

Labour economists have been increasingly interested in the impact of technological change upon employment and unemployment. However, the predominant focus of empirical studies has been on employment and unemployment stocks, whereas technological change is more likely to affect the flows of labour. This paper focuses on the latter issue. In particular, given the technological change, two major questions posed in this paper are: (i) who moves from low-tech to high-tech jobs and who moves from high-tech to low-tech jobs, and (ii) what are the factors which drive such movements. The data used in this study are from the 1994 Australian Labour Mobility Survey. A new index describing the technological level of a job is constructed and the magnitude and direction of movements along the technological ladder are examined. Using individual-level socio-economic variables, we explain the determinants of the direction of the job change. Some relevant policy implications are also discussed.

JEL Classification: J62, J63, O33

Keywords: job mobility, technological ladder, employment and unemployment flows

Corresponding author:

P.N. (Raja) Junankar

School of Economics and Finance

University of Western Sydney

Campbelltown Campus

Locked Bag 1797

Penrith South DC

NSW 1797

Australia

Email: raja.junankar@uws.edu.au

\footnotetext{
* This paper is a part of a project on Technological Change and Its Impact on Job Mobility in Australia which was sponsored by the Australian Research Council. We are grateful for helpful comments from Jeff Borland, Tom Crossley, and Bruce Chapman. Detailed comments from two anonymous referees helped to improve the paper. They are not of course responsible for any remaining errors. Amy Liu and Christine Benham provided valuable research assistance.
} 


\section{Introduction}

In recent years, there has been an increasing interest among labour economists in the impact of technological change upon the labour market. Most of these studies have focused on the impact of technological change on wage determination (see Dickens and Katz, 1987; Mincer, 1991; Topel, 1994; Krueger, 1993; Dunne and Schmitz, 1995; Goldin and Katz, 1996; Bartel and Sicherman, 1999; and Entorf and Kramarz, 1998). Some studies have also analysed the impact of technological change on the levels of employment and unemployment (see, for example, Kaplinsky, 1987; Northcott, 1984; Brouwer et al, 1993; de Wit; 1990; Davis and Haltiwanger, 1999; Meyer-Krahmer, 1992; OECD, 1994, Boyle and McCormack, 2002, and Fox, 2002). This study adds another dimension to these discussions by focusing upon the technological change perspective of job mobility.

Technological change has an important and complex impact on the dynamics of employment and unemployment. On the demand side, the introduction of new technology in one sector, especially if it is labour-saving or so-called skill-biased technology, will lead to an increase in labour productivity in that sector, which, ceteris paribus, will lead to a decrease in labour demand. However, this is not the only effect of labour-saving technological change on employment. While labour productivity increases, there will also be an associated decrease in the price of the good and an increase in income generally. These latter two effects, referred to as the final demand effect, may induce an increase in demand for that good, thereby generating higher demand for labour in that sector. The net impact of technological change on employment in one sector is, therefore, dependent upon which of the two effects, labour-saving or final demand, dominates.

Further, the final demand effect will not only affect the demand for goods and services in the sector in which the technological change occurred, but will also affect the demand for goods and services with high income elasticity which are produced in other sectors. Therefore, technological change may well bring an increase in employment in other sectors not directly affected by the technological change and hence, contribute to a structural change in employment throughout the economy. 
In addition, given heterogeneous nature of labour, the introduction of new technology may bring about an increased demand for highly skilled labour and a decrease in the demand for low skilled labour in that sector. At the same time, technological change in one sector will increase the demand for goods and services in other sectors. As these other sectors may require less-skilled labour, the demand for unskilled labour may still increase. The net effect on the demand for unskilled labour will depend upon the relative magnitudes of changes in the different sectors.

On the supply side, the initial supply of skills possessed by workers may not match the new level of demand for skilled and unskilled labour arising as a result of technological change and the consequent structural change in the economy. Thus, firing and quitting, training and re-training, as well as workers moving towards high-tech and low-tech jobs, will all occur simultaneously.

This complex picture of the relationship between technological change and job mobility is illustrated in Figure 1. On the demand side, both high-tech and low-tech jobs are created, while other jobs are destroyed as a result of technological change. On the supply side, those who lose jobs must obtain adequate skills to be able to (re-)gain employment in higher-tech jobs. Otherwise, they will have to get lower-tech jobs or become unemployed. This situation has been reviewed in The OECD Jobs Study (OECD, 1994). The basic conclusion of this work is that technological change creates jobs in some industries and occupations, but eliminates them in others. Thus, it re-distributes the workforce amongst sectors, occupations and skills, but does not produce significant unemployment.

As mentioned earlier, many studies, to date, have concentrated on the impact of technological change on the labour force stocks. To our knowledge, little research has been done on the resultant impact upon job changes and job mobility; which constitute the flows in the labour force (see Davis and Haltiwanger, 1999). This paper focuses on this dynamic aspect of the impact technological change. Three questions are consequently posed: (i) who moves from low-tech to high-tech jobs and who moves from high-tech to low-tech jobs: (ii) what are the factors which drive such movements.

Previous research which acknowledged the directional aspect of job mobility has primarily focused on individual occupational upgrading or downgrading (see, for example, 
Slifman, 1976, Sicherman and Galor, 1990, and Waddoups et al. 1995, Evans, 1999, Callus and Quinlan, 1979). There has also been substantial work analysing the relationship between wages and mobility (including a seminal paper by Borjas and Rosen, 1980). The underlying model of this stream of research is of an individual maximising the present value of lifetime income through a choice of lifetime job changes. McDonald and Felmingham, 1999, discuss the time series properties of mobility in Australia on an aggregative level. A recent survey, Farber, 1999, provides an interesting discussion, however, it does not consider the technological change aspect of labour mobility. Using Australian data on job mobility, this paper examines whether current job mobility in Australia follows an upward or downward move on (what we refer to as) the technological ladder and explains why it is so.

The paper is structured as follows. Section 2 describes the construction of the technological-level index and discusses the Australian Bureau of Statistics (ABS) Labour Mobility Survey data used in the study. Section 3 sets out the analytical framework. The empirical results are then presented in Section $4 .{ }^{1}$ Finally, Section 5 concludes the paper and discusses some policy implications.

\footnotetext{
${ }^{1}$ A review of recent changes in the structure of the Australian economy and their impact on the structure of employment and job mobility is included in an unpublished version of this paper available from the corresponding author.
} 
Figure 1. Schematic presentation of the impact of technological change on job mobility

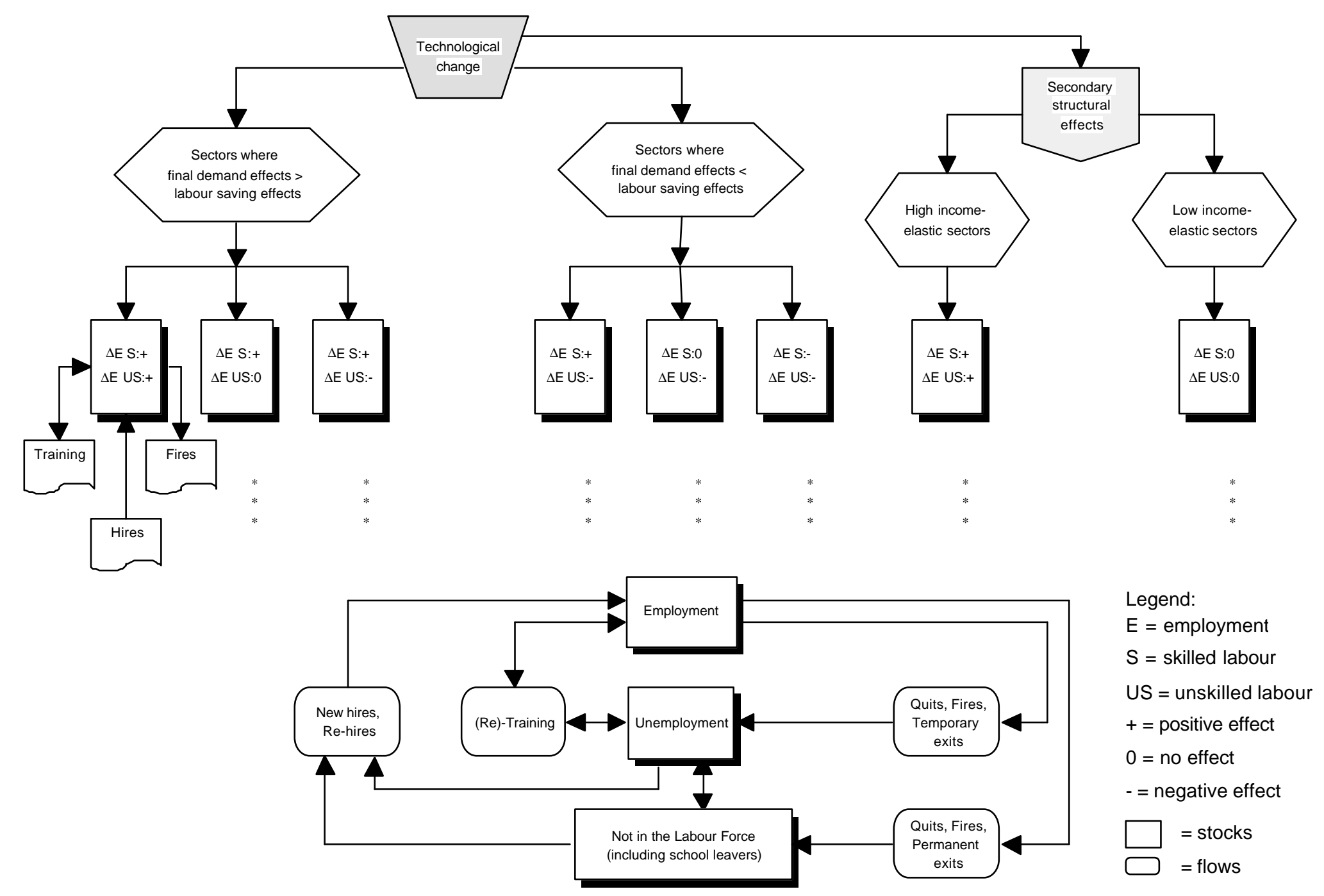




\section{Construction of the technological level of a job and data description}

To analyse the job mobility along the technological ladder, the first task is to rank the technological level of a job. Many studies have tried to rank jobs according to various criteria. Blau and Duncan 1967; Hauser and Featherman, 1977; Jones, 1989; and Najman and Bampton 1991; ranked occupations according to socio-economic status. Slifman 1976 used wage levels to rank occupations. Gordon, 1986 and Waddoups, Daneshvary, and Assane, 1995; ranked occupations in primary, subordinate primary and secondary segments according to labour market segmentation theory. Evans, 1999 uses the Goldthorpe-Hope index (based on social prestige) to study vertical occupational moves along this index. However, none of these criteria is suitable for measuring the technological level of a job.

A major difficulty in the empirical analysis of the relationship between technology and employment is the lack of a satisfactory measure of technology (its level or its change). Studies focusing upon the impact of technological change on labour market performance usually proxy technological change through measures such as the percentage of total investment spent on research and development (R\&D); innovation (patents) counts; the capital/labour ratio; total factor productivity growth; the percentage of employees who use a computer at work; or the percentage of highly educated employees (see, for example, Chapman and Tan, 1992; OECD, 1994; Krueger, 1993; and Goldin and Katz, 1996; Bartel and Sicherman, 1999). None of these proxies, however, is an adequate measure of technology level. More importantly, such measures are only available at an industry level, but not for different occupations.

Given that our interest is job mobility, the technological ranking to be chosen has to enable us to observe as much job mobility as possible. Given that any job entails at least two dimensions - industry and occupation - job mobility measure must include not only interindustry but also inter-occupational mobility. If we use any of the above measures to rank jobs, only inter-industry job mobility can be observed and intra-industry job mobility will be ignored. Moreover, the inter-occupational job change can be more important than interindustrial job change when the technological level of a job is concerned. For example, a truck driver's position in the mining industry should have a similar technological level as a truck driver's position in the manufacturing industry. But a truck diver's position in the 
mining industry certainly has a much lower technological level than an engineer's position in the same industry. Thus, a measurement of the technological level which takes both industrial and occupational dimensions into account would be more desirable.

The only two measurements which satisfy this criterion are the percentage of computer usage and the percentage of highly educated employees. However, as the available data for computer usage around the time of the labour mobility survey are from a survey with a relatively small sample size, many cells in the industry-occupation matrix are either empty or have very few observations. Hence, it would be problematic if computer usage were to be used to measure the technological level of jobs. Therefore, this study relies on the percentage of highly educated employees as the criterion for ranking the technology level of a job. ${ }^{2}$

Based on common sense, it may be argued that the higher the technological level, the higher the skill requirement for a job, and the higher the percentage of highly educated employees in such an occupation. As suggested by many economists, an industry that has a high rate of technological change would require more workers who can make frequent changes in job tasks and operating procedures. Highly educated workers are those who are more likely to adapt to change and to learn new technology (Jovanovic and Nyarko, 1995; Griliches, 1969; Nelson and Phelps, 1966; Bartel and Sicherman, 1997, Florida 2002). Moreover, Bartel and Sicherman, 1999, found that at higher rates of technological change, there is an increase in demand for the more educated workers. Thus, the percentage of highly educated employees is likely to be a good proxy for the technological level of a job.

Furthermore, many studies have found that technology and human capital are relative complements, (see, for example, Griliches, 1969; Goldin and Katz, 1996). Using Australian data, we can, for example, illustrate the close relationship between the percentage of highly educated employees and the percentage of the employees who use computers at work (see Table 1). Simple correlation coefficients between these two variables measured at various levels of disaggregation indicate that there is a very significant (generally, at better than 5 per cent significance level) relationship between these two variables. This relationship 
holds as one increases the aggregation level, although the increasing correlation reflects the reduced sample size (and, therefore, less variability in the data). As computer usage in a job is commonly used in the labour economics literature to capture the technological level of a job (see Krueger, 1993), the high correlation presented here indicates that the proxy used in this study is valid.

Table 1. Correlation coefficients between education measures and computer usage

\begin{tabular}{|c|c|c|c|c|c|}
\hline & \multicolumn{5}{|c|}{$\%$ of employees using a computer at work } \\
\hline & $\begin{array}{c}\text { Ind-occ } \\
\text { cells } \\
n=1186\end{array}$ & $\begin{array}{c}\text { Industry } \\
\text { (2 digit) } \\
n=46\end{array}$ & $\begin{array}{l}\text { Occupation } \\
\begin{array}{c}\text { ( } 2 \text { digit) } \\
n=51\end{array}\end{array}$ & $\begin{array}{c}\text { Industry } \\
\text { (1 digit) } \\
n=13\end{array}$ & $\begin{array}{c}\text { Occupation } \\
\text { (1 digit) } \\
n=8\end{array}$ \\
\hline$\%$ of degree and above & $\begin{array}{l}0.24^{\text {**** }} \\
(0.000)\end{array}$ & $\begin{array}{l}0.50^{* * * *} \\
(0.001)\end{array}$ & $\begin{array}{l}0.57^{* * *} \\
(0.000)\end{array}$ & $\begin{array}{l}0.65^{* *} \\
(0.016)\end{array}$ & $\begin{array}{c}0.68^{*} \\
(0.063)\end{array}$ \\
\hline$\%$ of secondary & $\begin{array}{c}0.03 \\
(0.311)\end{array}$ & $\begin{array}{c}0.24 \\
(0.12)\end{array}$ & $\begin{array}{c}-0.14 \\
(0.316)\end{array}$ & $\begin{array}{c}0.07 \\
(0.81)\end{array}$ & $\begin{array}{l}-0.13 \\
(0.75)\end{array}$ \\
\hline$\%$ of highly educated & $\begin{array}{l}0.26^{* * * *} \\
(0.000)\end{array}$ & $\begin{array}{l}0.56^{* * * *} \\
(0.000)\end{array}$ & $\begin{array}{l}0.54^{* * * *} \\
(0.000)\end{array}$ & $\begin{array}{c}0.64^{* * *} \\
(0.018)\end{array}$ & $\begin{array}{c}0.63^{*} \\
(0.093)\end{array}$ \\
\hline
\end{tabular}

Source: Authors' calculations using data from the ABS 1993 Training and Education Experience survey.

Note: The level of significance is presented in parentheses.

To define the technological level of each job, an industry-occupation matrix $A$ is generated, where a typical cell, $a_{i j}$, refers to the number of employees in occupation $\mathrm{i}$ in industry $\mathrm{j}$. In general, $a_{i j} \neq a_{j i}$. In this study, the two digit industry and occupation codings are used. This level of disaggregation provides for 45 industries and 52 occupations, and the number of cells, $a_{i j}$, in the matrix is, therefore, 2340.

For the purpose of this study, 1991 Australian Census data (Full Unit Record File) are used to calculate the percentage of highly-educated employees for each industryoccupation cell so that the sample size within each cell is big enough for the calculation and that the ranking used is independent of our sample. As a consequence, for each cell $a_{i j}$ in the industry-occupation matrix $A$ there is a corresponding education level defined as $\left[\frac{e d u_{i j}}{e m p_{i j}}\right]$. The cells in $A$ are then ranked according to $\left[\frac{e d u_{i j}}{e m p_{i j}}\right]$.

\footnotetext{
${ }^{2}$ Preliminary regression results and simple simulations reported in Junankar, Kapuscinski, and Meng, 1996, also revealed that education level is a significant determinant of job mobility, be it at the industry, occupation or regional level.
} 
The resultant ranking is called the Technological Level of a job $(T L)$. As there are two education levels that can be utilized (percentage with a degree or above and percentage with a secondary education or above but below degree), the cells are ranked according to two methods. In the first instance, the cells are ranked in order of $\left[\frac{\text { deg ree }_{i j}}{\text { emp }_{i j}}\right],\left[\frac{\text { sec ondary }_{i j}}{\text { emp }_{i j}}\right]$, respectively. ${ }^{3}$ This is referred to as RANK1. For the second method, the secondary qualification is weighted as 35 per cent of a degree qualification, with the weight based upon the differences in return to education between the two qualifications. ${ }^{4}$ This is referred to as RANK2. As some cells have the same percentage for each qualification and some cells are empty, the actual ranking for the 2340 cells is from 1 to $1384 .{ }^{5}$ The simple correlation coefficient between RANK 1 and RANK 2 is 0.9948 . Results with only RANK 1 are presented in the text and results using RANK 2 are in an Appendix B.

As has been mentioned, the data used in this study are from the 1994 Australian Labour Mobility Survey conducted by the ABS. This data set reports both the industry and occupation for the current job of an individual, as well as for job held by the individual 12 months ago. For each individual, we rank the current and previous jobs based on their technological level $(T L)$. Thus, $T L_{t}$ and $T L_{t-1}$ are obtained for every individual. The movement along the technological ladder $(M T L)$ variable is then derived by subtracting $T L_{t-1}$ from $T L_{t}$, such that: $M T L_{i j}=T L_{t}-T L_{t-1}$.

Individuals with a current job ranking, $T L_{t}$, greater than the previous job ranking, $T L_{t-1}$, are categorised as ascending the technological ladder; those who have equal ranking for both jobs are categorised as being stable: and those with current job ranked lower than previous job are categorised as descending the technological ladder.

The 1994 Australian Labour Mobility Survey sampled people who held a job at some time during the period from February 1993 to February 1994. This was a period of post-recessionary growth. The total sample is 39,049 individuals. Given that this study

\footnotetext{
${ }^{3}$ For example, if the ranking of two cells is identical according to the percentage of degree holders, then we rank the two cells according to the percentage of employees with secondary qualification.

${ }^{4}$ The weight " 0.35 " is chosen according to the relative coefficients on secondary and degree qualifications from the earnings equation for Australian wage and salary earners in 1990 to represent the productivity of the two types of employees (the associated coefficient for degree and above is 0.335 and for secondary is 0.11). The data used to estimate the wage equation are from ABS 1989-1990 Income Distribution Survey.
} 
focuses on the trend of individuals' job mobility along the technological ladder and its determinants, and that these questions are conditional upon individuals moving away from the original jobs, the sample used in this study is restricted to those who have changed from one job to another during the year February 1993 to February 1994, which excludes those who did not change jobs and those who entered employment from either unemployment or not in the labour force, or exited employment to either unemployment or not in the labour force. Among 39,049 individuals, 7,122 satisfy the job change definition in this study. However, upon further checking it was found that 2,703 individuals either had duration of the current job longer than 12 months (2,521 individuals) or stated the duration of the last job as 'not applicable' (282 individuals). Further, these 2,703 individuals' answer to the question "what is the reason for changing the job" was 'not applicable'. In order to ensure that the chosen sample accurately represents those who have actually changed jobs, these 2,703 individuals with respondent errors are excluded from the sample. ${ }^{6}$ This left a sample of 4,319 individuals, comprised of 2,506 men (58.02 per cent) and 1,813 women (41.98 per cent). ${ }^{7}$ Among this sample, 424 changed only occupation, 493 changed only industry, 1304 changed both occupation and industry, and the remaining 2098 changed job within their original industry-occupation cell.

Figure 2 presents the distribution of the variable MTL excluding those whose MTL is equal to zero (i.e. those who changed job within their original industry-occupation cell.). It is clear from this figure that our measure of job mobility is generally normally distributed. It is centred around its mean and it is symmetrical. The tails are very thin and the mass of the distribution is close to the mean. Finally the degree of dispersion is relatively narrow. ${ }^{8}$

\footnotetext{
${ }^{5}$ It is assumed that this ranking of industry-occupation cells is unchanged between 1991 and 1994.

${ }^{6}$ In the empirical estimation, these 2703 individuals will be included to test if the results are robust. Subsequently, the ABS has admitted that this variable has been mis -coded and the whole data has been revised.

${ }^{7}$ A data appendix (see Appendix A) presented at the end of the paper provides detailed statistical information on the variables used in this study.

${ }^{8}$ The mean of MTL is 4.38 , the variance is 110960 , the skewness is 0.01 and the kurtosis is 3.43 .
} 
Figure 2. The distribution of variable MTL

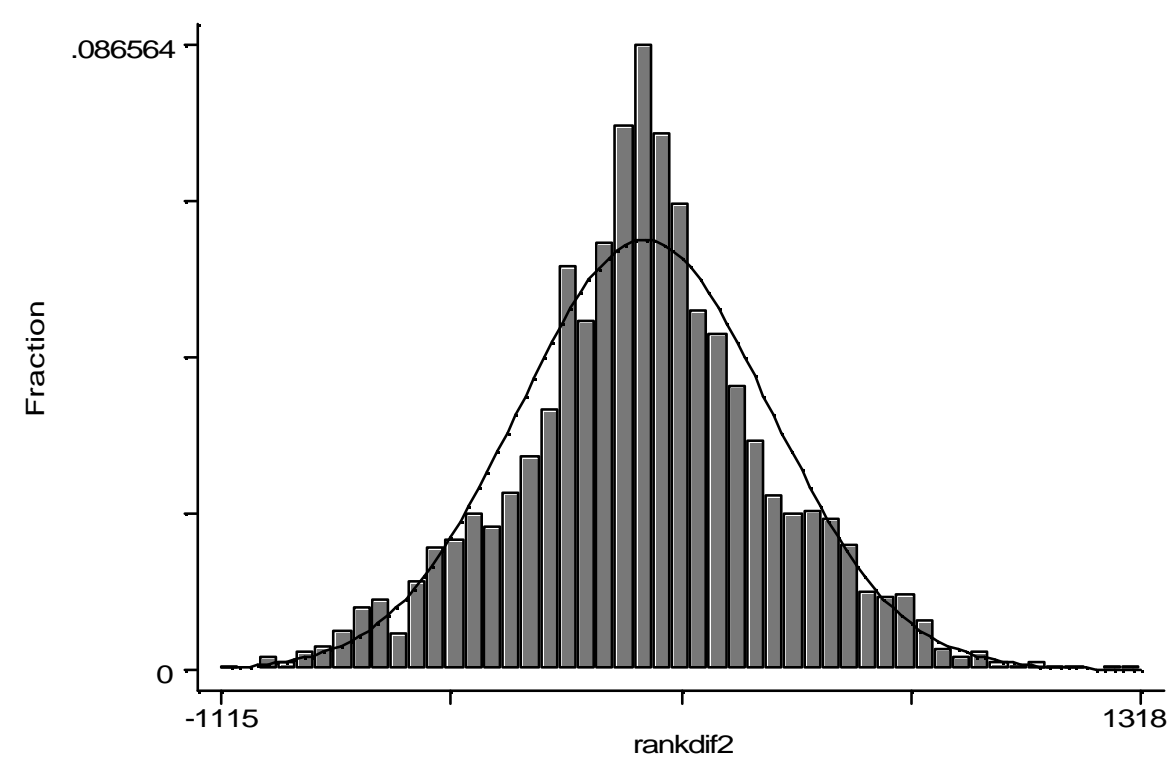

Note: The normal distribution is superimposed on the histogram of MTL.

Table 2 presents the average ranking of both the current and previous jobs as well as the ranking differences between the two jobs for men and women separately. Generally speaking, the average job ranking is slightly higher for the current job than for the previous job. Further, about 49 per cent of job mobility occurs at the same technological level (those 2098 individuals who changed job within the industry-occupation cell). The rest is almost equally distributed between moving-up and moving-down the technological ladder ( 26 per cent and 25 per cent, respectively). The story, however, differs between men and women. It appears that, on average, women possess jobs (both previous and current) which are at a higher level on the technological ladder than their male counterparts. Nevertheless, on average, women moved slightly down he technological ladder, while men moved up. In addition, slightly more women moved down when they changed jobs than was the case with men (26 per cent vs. 25 per cent). ${ }^{9}$

\footnotetext{
${ }^{9}$ A detailed examination of who moved up or down the technological ladder is presented in an unpublished version of this paper available from the corresponding author.
} 
Table 2. Job mobility along the technological ladder:

ranking based on RANK1

\begin{tabular}{l|cc|cc|cc}
\hline \hline & \multicolumn{2}{|c|}{ Total } & \multicolumn{2}{c|}{ Men } & \multicolumn{2}{c}{ Women } \\
& Mean & SD. & Mean & SD. & Mean & SD. \\
\hline Ranking for current job (1) & 674.4 & 380.6 & 592.8 & 420.3 & 787.1 & 281.4 \\
Ranking for previous job (2) & 672.1 & 380.1 & 588.0 & 419.3 & 788.4 & 279.2 \\
Ranking difference (1)-(2) & 2.3 & 238.7 & 4.8 & 255.5 & -1.2 & 213.3 \\
\hline Mobility along the TL: & Freq. & $\%$ & Freq. & $\%$ & Freq. & $\%$ \\
\hline Down & 1096 & 25.38 & 620 & 24.74 & 476 & 26.25 \\
Stable & 2101 & 48.65 & 1226 & 48.92 & 875 & 48.26 \\
Up & 1122 & 25.98 & 660 & 26.34 & 462 & 25.48 \\
\hline \hline
\end{tabular}

Source: Authors' calculation.

\section{Model specification}

Job mobility as a dynamic process reflects many aspects of a labour market. First a separation from one employer (voluntary or involuntary) is followed by search for another job and, if a match occurs, a creation of a new job. The employer may fire an employee or she may quit. The former depends on the employer's decision to remove an inefficient worker or due to demand or technological changes to reduce his/her workforce. The quitting decision is clearly based on the employee making a decision to leave to maximise lifetime utility. Whether the employee finds another job depends on both the employers' demand (whether there is a productive match) and the employee's decision to search and accept an offer based on the reservation wage/utility. Thus, to model job mobility, both demand and supply factors should be considered, see Farber 1999, Jovanovic, 1979, Williams, 1980.

This study is distinctive in that it analyses and an individual's mobility along the technological ladder. In other words, the model explains individuals' behaviour in relation to moving from a low-tech (relative to the current position) to a high-tech job, from a high-tech (again, relative to the current position) to low-tech job, or moving from one job to another without changing technological level.

The model, therefore, incorporates factors which may affect decision-making from the point of view of both suppliers and demanders regarding separation from a low-tech or a high-tech job, as well as moving into a high-tech or low-tech jobs. From the point of view of suppliers, job mobility along the technological ladder is assumed to be a function of individuals' lifetime maximised earnings (Borjas and Rosen, 1980), whereas employers 
choose employees so as to maximise firms' profits. Thus, the factors which may affect individuals earnings and labour productivity may have an impact on job mobility along the technological ladder. Apart from these micro-level factors, the macro-economic environment also affects individuals' job mobility behaviour. For example, in a recession, individuals may be reluctant to quit jobs. Hence, the variables that should be included in the model are: individuals' human capital variables, individuals' family background, wage differentials between the current and previous job, characteristics of the previous job, and general macro-economic indicators. This reduced form model may, thus, be expressed as:

$$
M T L_{i j}=f\left(H, W_{d i f}, F, J o b_{i}, E_{\text {macro }}\right)
$$

where $M T L_{i j}$ is mobility along the technological ladder from ranking $i$ to ranking $j . H$ and $F$ are vectors of human capital variables and family background variables, respectively. $W_{d i f}$ is the wage differential between the previous and current jobs. $J o b_{i}$ is a vector of characteristics of individuals' previous job, and $E_{\text {macro }}$ is a vector of macro-economic indicators.

Generally speaking, individuals with greater human capital endowment are more likely to move up the technological ladder. However, the impact of firm-specific training may be ambiguous (Waddoups et al., 1995, Farber, 1999). This is because, on the one hand, the longer one stays in a given job, the more unsuitable one becomes for a higher-technology job. On the other hand, individuals may obtain skills (re-training) and experience in one job in order to move to a higher-technology level job. Thus, the effect of firm-tenure on job mobility along the technological ladder is a purely empirical question. In this study we include potential labour market experience (Mincer's (1958) definition); firm-tenure for the job held 12 months ago; and dummy variables for education including a dummy variable for tertiary qualification and above, a dummy variables for completed secondary and other technical and further educational qualifications. Below secondary is used as the default group. In addition, as new degree holders are more likely to enter the labour market at a relatively low level and more likely to find more suitable jobs later on, a interaction term between dummy variable for degree and above and age is included.

The wage differential between individuals' previous and current job should play an important role in affecting individuals' job mobility behaviour. This variable is not included in 
the regression analysis as the data set used in this study did not contain this information. However, since our explanatory variables include most of the variables that are usually employed to explain wages in estimated earning functions we would gain little from using predicted wages (which could, in fact, lead to multicollinearity problems).

Family background variables capture the effect of family responsibility on individuals' job mobility behaviour. In this study, we combine the effect of marital status and the number of children into a group of dummy variables for family type: married couple with children, married couple without children, single parent family, and single person fimily, where the single person family is used as the default.

As for characteristics of the previous job, two available variables, namely full/part time job and whether individuals were self-employed are included. A group of industry dummy variables for individuals' previous job is also included. Apart from these, to control for the 'initial effect', the technological ranking of one's previous job is also included. This initial effect suggests that those who started with high ranking jobs are less likely to move further up (especially those who started with top ranking jobs) than those who started with low ranking jobs. Essentially, this allows for convergence of individuals along this technological ladder. If they are high up on the ladder they go down, while if they are low down they are likely to move up. For this convergence to be observed the parameter estimate on the technological rank of the previous job should be negative and less than one. This is analogous to the finding of convergence in the growth literature, see Romer, 1996, (p. 27).

In addition, three variables of individual characteristics are also included. They are a dummy variable for migrants from non-English speaking backgrounds (NESB), a dummy variable for those who were retrenched from the previous jobs, and a dummy variable for male workers. NSEB migrants are expected initially to find a lower level job and to move later on to a position reflecting their skill-level. On the other hand, individuals who were retrenched from the previous jobs are expected to be less likely to move up the technological ladder. This is because a person who is retrenched is unlikely to be as particular in his/her job search and job acceptance. In addition, employers are likely to use retrenchment as a signal of personal quality during their hiring process. Preliminary analysis 
revealed that gender may play an important part in individuals' behaviour of job mobility along the technological ladder.

Finally, the macro-economic environment is controlled by a group of regional dummy variables for the location of the previous job.

To sum up, Equation (1) can be specified as ${ }^{10}$ :

$$
\begin{aligned}
\text { MTL }_{i j} & =\beta_{0}+\beta_{1} \text { Exp }+\beta_{2} \text { Exp }^{2}+\beta_{3} \text { Tenure }_{i}+\beta_{4} \text { Edu }+\beta_{5} \text { Family } \\
& +\beta_{6} \text { F/ Ptime } \\
& +\beta_{7} \text { Selfemp }_{i}+\beta_{8} \text { Re trench }+\beta_{9} \text { Sex } \\
& +\beta_{10} \text { Rank }_{i}+\beta_{11} \text { Industry }+\beta_{12} \text { Re gion }
\end{aligned}
$$

where Edu, Family, Industry, and Region are vectors of dummy variables for education level, family type, industry affiliation, and region, respectively. The methodology of estimation and estimated results are discussed in the next section.

\section{Empirical results}

The dependent variable $M T L$ used in this study can be expressed in two different forms: (1) a difference $\left(T L_{t}-T L_{t-1}\right)$, which will produce a semi-continuous variable with the property of $M T L_{i j}[-1384,1384] .{ }^{11}$ (2) an index which categorises $M T L$ into three bands (less than zero, equal to zero, and greater than zero), which will produce a discrete variable. If the first format of the $M T L$ is used as the dependent variable, an $O L S$ estimation may be adopted. The possible flaw with this estimation is that the dependent variable is bounded. If the categorised variable is used as the dependent variable, an ordered-probit model can be estimated. This estimation, however, raises the issue of having a wide range of rankings in one category. ${ }^{12}$ For example, within the category of moving up the ladder, MTL can assume values from 1 to 1384 . An individual who moves up one rank certainly should not be considered the same as one who moves up, say, 1000 rankings.

\footnotetext{
${ }^{10}$ Note that unlike Kilpatrick and Felmingham, 1996, the tenure variable used in this study is the tenure of last job. The reason for this is that the dependent variables in both our study and their study are an event which happened before the current job started. Thus, the variable 'tenure for the current job' has nothing to do with it. If anything, it should be firm-specific training (proxied by job tenure) that an individual has obtained before job mobility which may have an impact on job mobility.

${ }^{11}$ Recall that the total rankings of occupation-industry cells is 1384 levels. Thus, for an individual moving from one job to another the minimum ranking difference between the two job is -1383 , and the maximum is 1383 .

${ }^{12}$ The average value for the category of moving-up is 254 and moving-down is -252 . The range for the two groups are: 1 to 1318 and -1115 to -1 .
} 
Bearing these problems in mind, Equation 2 is estimated by both $O L S$ and orderedprobit regressions. The results are robust, regardless of which methodology and which dependent variable is used. In addition, we realise that ignoring transitions out of employment may introduce some selection bias. To deal with this problem, a Heckman two stage sample selection model (see Borjas and Rosen, 1980) is estimated - see Appendix Table B3. The sample selection equation used age and occupational dummies which gave a very significant lamda. The results indicate that accounting for the selection bias does not change the main story obtained from the OLS estimation. Thus, the results for $O L S$ estimation are reported in Table $3 .^{13}$

\footnotetext{
${ }^{13}$ The results reported in Table 7 are from OLS regressions with RANK1 as the dependent variable. The results from ordered-probit model and that with RANK2 as the dependent variable are reported in Tables B1 and B2 (see Appendix B). The Heckman sample selection model is reported in Table B3.
} 
Table 3. OLS estimation of Equation 2: dependent variable is $\mathrm{TL}_{\mathrm{t}}-\mathrm{TL}_{\mathrm{t}-1}$

\begin{tabular}{|c|c|c|c|c|c|c|}
\hline & \multicolumn{2}{|c|}{ Total } & \multicolumn{2}{|c|}{ Male } & \multicolumn{2}{|c|}{ Female } \\
\hline & Coeff. & T-ratio & Coeff. & T-ratio & Coeff. & T-ratio \\
\hline Constant & 165.45 & $7.51^{* * * *}$ & 83.81 & $2.92^{* * * *}$ & 270.39 & $7.22^{* * *}$ \\
\hline Labour market experience & 2.82 & $2.37^{* * *}$ & 3.73 & $2.24^{* *}$ & 2.13 & 1.27 \\
\hline Labour market experience $^{2}$ & -0.04 & -1.28 & -0.05 & -1.25 & -0.03 & -0.81 \\
\hline Age for degree holders & -3.58 & $-3.95^{* * *}$ & -5.26 & $-3.89^{* * *}$ & -2.75 & $-2.31^{* *}$ \\
\hline Degree and above qualification & 275.37 & $8.15^{* * * *}$ & 373.66 & $7.12^{* * * *}$ & 215.61 & $5.04^{* * *}$ \\
\hline Secondary education & 40.73 & $3.87^{* * * *}$ & 63.97 & $4.20^{* * * *}$ & 10.84 & 0.78 \\
\hline Technical \& further education & 6.42 & 0.70 & 5.21 & 0.42 & 12.67 & 0.96 \\
\hline Married couple with kids & -14.63 & -1.54 & -20.03 & -1.56 & -5.96 & -0.42 \\
\hline Married couple without kids & -13.92 & -1.53 & -14.29 & -1.08 & -16.29 & -1.38 \\
\hline Single parent family & 30.56 & 1.27 & 98.20 & 1.36 & 27.41 & 1.18 \\
\hline Working full time previously & 5.15 & 0.60 & 3.52 & 0.23 & 12.83 & 1.28 \\
\hline Self-employed previously & 4.23 & 0.33 & 5.36 & 0.33 & -1.18 & -0.06 \\
\hline Non-Eng. speaking migrants & 2.57 & 0.22 & 7.83 & 0.48 & -5.98 & -0.36 \\
\hline Dummy for males & -38.49 & $-5.02^{* * *}$ & & & & \\
\hline Being retrenched & -26.71 & $-2.93^{* * * *}$ & -21.25 & $-1.75^{*}$ & -30.61 & $-2.27^{* *}$ \\
\hline Tech-level for previous job & -0.31 & $-25.54^{* * *}$ & -0.29 & $18.41^{* * * *}$ & -0.37 & $-19.48^{* * *}$ \\
\hline \multicolumn{7}{|l|}{ Industry of previous job: } \\
\hline Manufacturing & -4.76 & -0.26 & -5.77 & -0.26 & -4.86 & -0.14 \\
\hline Construction & -37.07 & $-1.90^{*}$ & -27.88 & -1.21 & -17.46 & -0.40 \\
\hline Trade & 10.53 & 0.62 & 15.14 & 0.72 & -8.42 & -0.26 \\
\hline Transport and storage & -27.10 & -1.26 & -30.60 & -1.17 & -10.74 & -0.26 \\
\hline Communication & -0.55 & -0.02 & -13.10 & -0.37 & 22.94 & 0.48 \\
\hline Finance & 26.78 & 1.47 & 34.20 & 1.46 & -3.68 & -0.11 \\
\hline Public administration & 46.58 & $2.10^{* *}$ & 54.53 & $1.93^{*}$ & 26.62 & 0.69 \\
\hline Community service & 2.71 & 0.15 & 19.91 & 0.81 & -15.01 & -0.46 \\
\hline Recreation & -45.94 & $-2.47^{* * *}$ & -67.34 & $-2.69^{* * *}$ & -48.27 & -1.48 \\
\hline \multicolumn{7}{|l|}{ Region of previous job: } \\
\hline NSW & 8.29 & 0.80 & 19.49 & 1.33 & -12.23 & -0.87 \\
\hline QLD & 7.31 & 0.69 & 19.67 & 1.32 & -8.56 & -0.60 \\
\hline SA & 5.61 & 0.46 & 30.89 & $1.80^{*}$ & -26.64 & -1.61 \\
\hline WA & -14.61 & -1.27 & 4.59 & 0.29 & -51.02 & $-3.20^{* * *}$ \\
\hline TAS & 3.15 & 0.19 & 43.06 & $1.89^{*}$ & -46.74 & $-2.12^{* *}$ \\
\hline NT & 10.34 & 0.47 & 49.84 & 1.54 & -35.55 & -1.23 \\
\hline $\mathrm{ACT}$ & 28.80 & $1.67^{*}$ & 70.93 & $2.77^{* * *}$ & -17.46 & -0.79 \\
\hline $\begin{array}{l}\text { Number of observations } \\
\text { Adjusted } \mathbf{R}^{2}\end{array}$ & \multicolumn{2}{|c|}{$\begin{array}{r}4319 \\
15.5\end{array}$} & \multicolumn{2}{|c|}{$\begin{array}{r}2506 \\
15.2\end{array}$} & \multicolumn{2}{|c|}{$\begin{array}{r}1813 \\
18.9\end{array}$} \\
\hline
\end{tabular}

Source: Authors' estimation.

Note: $\mathrm{t}$-statistic values with $* * *$ are significant at the 1 per cent level; ** at the 5 per cent level; * at the 10 per cent level.

For the total sample estimation (columns 1 and 2), human capital variables appear to play positive and significant roles in determining individuals' mobility towards high-tech position. One more year of labour market experience increases an individual's upward job move by 2.7 rankings initially. ${ }^{14}$ On average, in comparison to those who obtained less than

\footnotetext{
${ }^{14}$ The quadratic term of labour market experience is not statistically significant in this estimation.
} 
secondary education, those with tertiary qualifications and those who only completed secondary education moved 275 and 41 levels higher, respectively. This effect is very robust even when the possibility of young people and women more likely to start with a job for which he/she is overqualified while shopping for a better job is controlled for (see the result in columns 5 and 6 for female sample only). The variable "age for degree holders" controls for the young graduate effect. When the regression is estimated for women only with age interacted with degree holder, we still observe very strong positive educational effect (those with degree and above qualification move up 215 units in comparison to the less than secondary qualification holders. On the other hand, having a technical or vocational qualification does not help individual moving towards high-tech jobs. Given that firm-specific training does not matter in terms of upward job mobility, it was excluded from the regression.

Individuals' family background and the characteristics of the previous job do not seem to be statistically significant. Migrants who are from non-English speaking countries are, in general, not in an inferior position as far as upward job mobility is concerned. Women are doing much better in terms of job mobility along the technological ladder. On average, they are 39 levels ahead of their male counterparts.

The reason for cessation of the previous job does play a significant role. Those who were retrenched from the last job on average moved 27 rankings lower than otherwise. At the same time, the so-called 'initial effect' is also a very important factor. The negative and significant tratio for this variable suggests that people who started from low-tech jobs, controlling for personal characteristics, are more able to move up the technological ladder.

Among the industry dummy variables agriculture, mining and electricity are used as a default group. ${ }^{15}$ Compared to this group, those who previously worked in the public administration sector are more likely to move up the technological ladder when they change jobs. On the other hand, those who previously worked in the recreation or construction industries moved further down the technological ladder in relation to their counterparts in the default group. This may indicate that compared to the default group, employees in the public administration industry obtained more appropriate training for moving towards higher-tech 
jobs, whereas employees from the construction and recreation industries obtained less adequate training.

Finally, apart from Australian Capital Territory (ACT), regional dummy variables (compared to the default group of Victoria) do not seem to play any significant role in this model.

Considering the fact that gender plays an important part and that women have different family responsibilities which may affect their job mobility decision-making, Equation 2 is estimated for men and women separately (columns 3 to 6 of Table 4). ${ }^{16}$

The main differences in the behaviour pattern between the two gender groups are as follows. First, as Mincer's potential experience measure over-estimates female labour market experience, the estimated result for labour market experience is insignificant for females.

Second, women with equal qualifications moved up less than their male counterparts when they change jobs. The difference between men and women with tertiary qualification is 168 rankings. Women with high school qualification do not do better than those without high school qualification, whereas men with high school qualification move 64 rankings ahead of those without high school qualification. This result seems to suggest that the market undervalues women's qualification.

Third, being retrenched worsens the female job moving opportunity much more than that for men. On average, being retrenched demotes women by about 10 rankings lower than it does men.

Fourth, there is no industry effect in female job mobility along technological ladder. This, however, is not the case for men. Men who worked previously in the public administration sector on average moved 54 rankings higher than those who previously worked in the agricultural, mining, and electricity industries. In contrast, men who previously

\footnotetext{
${ }^{15}$ The reason for grouping the three sectors as the default group is that each industry has been declining in employment following the 1982 recession.

${ }^{16}$ An F-test is conducted to see if the behavioural difference between men and women is statistically significant. The test result is : $F(30,4257)=2.81$, which is greater than the critical value of $F(30, \infty)=1.79$, suggesting that the difference is significant at the 1 per cent level.
} 
worked in the recreation sector moved 67 rankings lower in comparison to the default group.

Finally, males in the ACT, South Australia and Tasmania are doing better than their counterparts in Victoria while women in Western Australia and Tasmania are doing worse than women in Victoria. This may reflect the impact of a regional economic structural differential and a regional economic environment differential on demand for men and women employees. Compared to Victoria (the default case), women in all the states do worse, while men do better.

The other possible behavioural difference may be observed between voluntary and involuntary job movers. An F-test suggests that the structural difference between voluntary and involuntary job movers is statistically significant. ${ }^{17}$ To detect this differential, the total sample is disaggregated into two groups: involuntary (being retrenched) and voluntary movers. The re-estimations of Equation 2 for the disaggregated sample are reported in columns 1 to 4 in Table 5.

The main behavioural differences between the total involuntary and voluntary groups are observed as the impact of human capital, family background, industrial and regional variables on individuals' job mobility along the technological ladder. Possession of a secondary degree does not affect the direction and magnitude of involuntary movers' job mobility along the technological ladder while it does so for the voluntary movers. More interestingly, for those voluntary movers who possess tertiary qualifications, the younger they are the more likely they will move up the technological ladder. This relationship, however, does not apply to involuntary movers. This suggests less choices for involuntary movers when they move jobs.

Family background seems to affect involuntary movers more than it does voluntary movers. One interesting finding is that single parents seem to do better than single persons in terms of job mobility along the technological ladder. One possible explanation is that to be able to support their children, single parents try harder in the labour market, especially when

\footnotetext{
${ }^{17}$ The F-test is conducted by adding a set of interaction terms between variables included in Equation 2 and the dummy variable for retrenched, and then testing if those interaction terms as a whole are significantly different from zero. The result is: $F(30,4257)=2.38$, which is greater than the critical value:
} 
they are retrenched. On the contrary, married couples with children performed less impressively.

Table 4. Estimation of Equation 2: voluntary vs involuntary mobility

\begin{tabular}{|c|c|c|c|c|c|c|c|c|}
\hline & \multirow{2}{*}{\multicolumn{2}{|c|}{$\begin{array}{c}\text { Involuntary } \\
\text { Total }\end{array}$}} & \multicolumn{6}{|c|}{ Voluntary } \\
\hline & & & \multicolumn{2}{|c|}{ Total } & \multicolumn{2}{|c|}{ Male } & \multicolumn{2}{|c|}{ Female } \\
\hline & Coeff. & T-ratio & Coeff. & T-ratio & Coeff. & T-ratio & Coeff. & T-ratio \\
\hline Constant & 233.24 & $4.13^{* * * *}$ & 147.70 & $6.23^{* * *}$ & 74.66 & $2.40^{* * *}$ & 232.77 & $5.64^{* * * *}$ \\
\hline Labour market experience & 5.61 & $1.87^{*}$ & 2.37 & $1.83^{*}$ & 3.44 & $1.87^{*}$ & 1.39 & 0.78 \\
\hline Labour market experience $^{2}$ & -0.11 & -1.55 & -0.02 & -0.71 & -0.04 & -0.86 & -0.02 & -0.35 \\
\hline Age for degree holders & -1.93 & -0.60 & $-3.94^{* * *}$ & $-4.19^{* * *}$ & -6.42 & $-4.54^{* * *}$ & -1.87 & -1.52 \\
\hline Degree and above qualification & 274.73 & $2.12^{* *}$ & 282.14 & $8.10^{* * * *}$ & 397.07 & $7.29^{* * * *}$ & 193.63 & $4.39^{* * *}$ \\
\hline Secondary education & 45.05 & 1.61 & 41.24 & $3.65^{* * *}$ & 61.90 & $3.76^{* * * *}$ & 13.11 & 0.88 \\
\hline Technical \& further education & -29.69 & -1.28 & 14.10 & 1.43 & 13.79 & 1.01 & 16.37 & 1.17 \\
\hline Married couple with kids & -51.44 & $-1.99^{* *}$ & -7.09 & -0.70 & -10.94 & -0.78 & 0.39 & 0.03 \\
\hline Married couple without kids & -6.69 & -0.27 & -14.71 & -1.53 & -8.96 & -0.62 & -21.61 & $-1.74^{*}$ \\
\hline Single parent family & 121.56 & $1.91^{*}$ & 14.76 & 0.57 & 43.65 & 0.53 & 15.69 & 0.63 \\
\hline Working full time previously & -31.17 & -1.25 & 10.32 & 1.13 & 7.60 & 0.47 & 17.46 & $1.65^{*}$ \\
\hline Self-employed previously & 34.52 & 0.84 & 0.94 & 0.07 & -4.27 & -0.25 & 8.99 & 0.43 \\
\hline Non-Eng. Speaking migrants & -10.99 & -0.38 & 4.72 & 0.36 & 4.58 & 0.25 & 5.70 & 0.31 \\
\hline Dummy for males & -64.72 & $-2.82^{* * *}$ & -34.69 & $-4.31^{* * *}$ & & & & \\
\hline Tech-level for previous job & -0.44 & $13.06^{* * *}$ & -0.28 & $22.05^{* * *}$ & -0.26 & $15.20^{* * *}$ & -0.36 & $17.84^{* * * *}$ \\
\hline \multicolumn{9}{|l|}{ Industry of previous job: } \\
\hline Manufacturing & 26.66 & 0.61 & -17.06 & -0.85 & -30.70 & -1.26 & 22.36 & 0.58 \\
\hline Construction & 9.91 & 0.22 & -58.20 & $-2.67^{* * *}$ & -51.13 & $-1.97^{* *}$ & -34.11 & -0.72 \\
\hline Trade & 29.73 & 0.69 & 4.25 & 0.23 & 2.56 & 0.11 & 8.44 & 0.24 \\
\hline Transport and storage & -3.21 & -0.06 & -34.64 & -1.48 & -43.14 & -1.53 & 6.14 & 0.13 \\
\hline Communication & -13.74 & -0.18 & 3.68 & 0.12 & -28.06 & -0.74 & 68.68 & 1.33 \\
\hline Finance & 17.85 & 0.36 & 21.36 & 1.09 & 21.06 & 0.84 & 17.55 & 0.48 \\
\hline Public administration & 167.89 & $2.72^{* * * *}$ & 21.02 & 0.89 & 26.06 & 0.87 & 19.78 & 0.47 \\
\hline Community service & 4.41 & 0.09 & -3.73 & -0.19 & 7.10 & 0.27 & 1.54 & 0.04 \\
\hline Recreation & -53.25 & -1.12 & -43.58 & $-2.17^{* *}$ & -68.80 & $-2.53^{* * *}$ & -25.08 & -0.69 \\
\hline \multicolumn{9}{|l|}{ Region of previous job: } \\
\hline NSW & 1.21 & 0.04 & 11.60 & 1.04 & 19.80 & 1.23 & -4.21 & -0.28 \\
\hline QLD & 21.13 & 0.75 & 5.29 & 0.47 & 14.80 & 0.91 & -4.16 & -0.28 \\
\hline SA & 2.77 & 0.08 & 5.19 & 0.41 & 23.52 & 1.28 & -16.54 & -0.96 \\
\hline WA & -19.54 & -0.62 & -11.60 & -0.95 & 7.48 & 0.43 & -42.57 & $-2.53^{* * *}$ \\
\hline TAS & 43.48 & 0.96 & -3.27 & -0.19 & 29.01 & 1.19 & -35.31 & -1.52 \\
\hline NT & -74.25 & -1.03 & 19.09 & 0.83 & 61.74 & $1.84^{*}$ & -26.08 & -0.86 \\
\hline ACT & 12.72 & 0.27 & 31.21 & $1.70^{*}$ & 60.27 & $2.20^{* * *}$ & 2.57 & 0.11 \\
\hline $\begin{array}{l}\text { Number of observations } \\
\text { Adjusted } \mathbf{R}^{2} \\
\end{array}$ & \multicolumn{2}{|c|}{$\begin{array}{r}742 \\
23.6 \\
\end{array}$} & \multicolumn{2}{|c|}{$\begin{array}{l}3577 \\
13.9 \\
\end{array}$} & \multicolumn{2}{|c|}{$\begin{array}{l}2006 \\
12.8 \\
\end{array}$} & \multicolumn{2}{|c|}{$\begin{array}{l}1571 \\
18.7 \\
\end{array}$} \\
\hline
\end{tabular}

Source: Authors' estimation.

$F(30, \infty)=1.79$, suggesting that the null-hypothesis of the set of interact terms are equal to zero can be rejected at the 1 per cent significance level. 
Note: t-statistic values with $* * *$ are significant at the 1 per cent level; ** at the 5 per cent level; * at the 10 per cent level.

Having previously worked in the public sector makes involuntary movers better off in terms of finding a higher-tech job. This, however, does not affect voluntary movers in the same way. For voluntary movers, previous employment in the construction or recreation sectors is disadvantageous when moving along the technological ladder. Regional dummy variables do not affect involuntary movers' job mobility pattern, however, voluntary movers previously working in the ACT gain a certain advantage.

The above description is based on the results for the total sample of voluntary and involuntary groups. However, within each group, gender differentials may still play a significant part. Interestingly, F-tests suggest that this is the case for the voluntary movers but not for the involuntary movers. ${ }^{18}$ Thus, the voluntary mover group is further disaggregated by gender. Some additional findings are revealed (see columns 5-8 in Table 4). First of all, female voluntary movers who previously worked on a full-time basis are better off than those who previously worked part-time, while this characteristic does not affect male voluntary movers. Closer examination of the data suggests that among this group of females, 39 per cent were previously part-time workers; whereas only 13 per cent of their male counterparts were formerly part-time workers. While male part-time workers, on average, moved up 4 rankings, their female counterparts moved down 4 rankings (see Table 5). This finding may indicate a lack of adequate training for female part-time workers.

Table 5. Job mobility along the technological ladder by gender and full- or part-time work

\begin{tabular}{l|cccc}
\hline \hline TL-TL -1 & Mean & S.D. & Freq. & \% of total \\
\hline Men & & & & \\
part-time previously & 3.96 & 307.17 & 263 & 0.13 \\
full-time previously & 3.59 & 233.29 & 1736 & 0.87 \\
Total & 3.63 & 244.20 & 1999 & 1.00 \\
\hline \hline Women & & & & \\
part-time previously & -3.84 & 212.31 & 616 & 0.39 \\
full-time previously & 4.87 & 205.46 & 954 & 0.61 \\
Total & 1.45 & 208.15 & 1570 & 1.00 \\
\hline \hline
\end{tabular}

Source: Authors' calculation.

\footnotetext{
${ }^{18}$ The F-test result for the involuntary movers is $F(29,682)=1.48$, and for the voluntary movers: $F(29$, $3517)=2.48$, whereas the critical value is $F(29, \infty)=1.81$
} 
Second, family background seems to affect male and female voluntary movers in different ways. Married couples without children in the voluntary female group are doing worse than their single counterparts.

The basic pattern obtained from an OLS estimation is similar to the results from an ordered-probit estimation (see Appendix B, Table B1). The only differences lie in the impact of some industry and regional dummy variables. ${ }^{19}$

To sum up, by controlling for the initial-effect, individuals with longer labour market experience and higher education moved higher up the technological ladder in comparison to those who possess less human capital endowment. This seems to apply to both male and female voluntary movers. However, when involuntary movers are examined then, apart from tertiary qualification, human capital does not generally affect the direction and magnitude of their job mobility along the technological ladder.

In the voluntary movers' group, women previously working part-time may bring forth a disadvantage to their job mobility along the technological ladder. In the case of men, this effect is negligible.

Finally, voluntary movers who previously worked in the recreation and construction sectors normally move down the technological ladder when they move jobs, whereas involuntary movers who previously engaged in the public sector are generally better off in this regard.

All these findings indicate that training, including formal training, retraining, and learning by doing, are the most important factors affecting the direction of voluntary movers' job mobility along the technological ladder. As for the involuntary movers, the most important factors are family background and regional differentials.

\section{Conclusions}

As a stepping stone towards understanding how technological change affects job mobility, this study has contributed to the existing literature in the following ways. First, a

\footnotetext{
${ }^{19}$ The estimation is conducted including the sub-sample of individuals with respondent errors. The results show that the inclusion of this sub-sample do not vary the basic findings.
} 
new variable is constructed which ranks job mobility according to a technological level. This enables one to quantify job mobility in accordance with technological change.

Second, the magnitude and direction of job movements along the technological ladder is investigated using the ABS 1994 Australian Labour Mobility Survey data. This resulted in an observation that about 50 per cent of mobile workers moved to a job which had the same technology level as the previous one, while the rest of the movers are about equally distributed between ascending and descending groups.

Third, a model is set up to explain the direction and magnitude of mobility along the technological ladder. The results indicate that, apart from gender differences, voluntary movers with more appropriate formal and informal training are more likely to move up the technological ladder.

Training and re-training, therefore, seem to be one of the most important issues in a world where technological and structural changes are taking place. If one assumes that hightech implies high productivity, then pushing more people from low-tech jobs to high-tech jobs would be essential for an economy to gain a sustainable high growth rate.

Another policy issue relates to gender-specific training. It seems likely that in this changing world, women are doing better than men. This is not only because more women possess higher qualifications than men, but also because there may be some unexplained differentials between the two gender groups. 


\section{Appendix A: Detailed description of variables used in this study}

Labour market experience: Mincer's definition. Exp=Age-Years of Schooling-5

Education: A set of dummy variables is constructed:

1. Degree: those who obtained degree and above qualification equals one, zero otherwise

2. Secondary: those who obtained secondary education or above but below degree equals one, zero otherwise.

Firm tenure for last job: This variable is reported in the survey data.

Family type: A set of three dummy variables is constructed.

1. Married couple with children

2. Married couple without children

3. Single parent family

Working full time previously: Those who reported working full-time for the last job (12 months ago) equals one, otherwise equals zero.

Self-employed previously: those who reported working as self-employed for the last job (12 months ago) equals one, otherwise equals zero.

Non-English speaking migrants: Those who reported as migrants from non-English speaking background equals one, otherwise equals zero.

Being retrenched: In the questionnaire one question asks the reason for quitting the last job. The choices are: (1) Retrenched; (2) Job was temporary or seasonal and did not leave to return to studies; (3) Own ill health or injury; (4) Unsatisfactory work conditions; (5) Job was temporary or seasonal and left to return to studies; (6) Retired, new business, better job, family or other reasons; (7) Employment reasons; (8) Personal reasons; (8) Other reasons. Among all these choices, retrenched is the only one which has a clear-cut demand effect. Thus, the variable 'Being Retrenched' 
is constructed, thereby those who choose 'Retrenched' equals one, otherwise equals zero.

Technological level for previous job: $T L_{t-1}$

Industry for previous job: This is a group of dummy variables of industry affiliation of individuals' previous job. Agriculture, Mining, and Electricity are set as the default group.

Region for previous job: A group of regional dummy variables for the state locations of individuals' last job. Victoria is set as the default group.

Descriptive statistics of the variables used in the study

\begin{tabular}{|c|c|c|c|c|c|c|}
\hline & \multicolumn{2}{|c|}{ Total } & \multicolumn{2}{|c|}{ Males } & \multicolumn{2}{|c|}{ Females } \\
\hline & Mean & SD. & Mean & SD. & Mean & SD. \\
\hline Current ranking & 674.37 & 380.64 & 592.79 & 420.27 & 787.14 & 281.36 \\
\hline Previous ranking & 672.12 & 380.12 & 588.01 & 419.30 & 788.38 & 279.21 \\
\hline Current rank-previous rank & 2.25 & 238.70 & 4.77 & 255.50 & -1.24 & 213.31 \\
\hline Labour market experience & 15.37 & 10.92 & 16.29 & 10.94 & 14.09 & 10.78 \\
\hline Dummy for tertiary education & 0.18 & 0.39 & 0.15 & 0.36 & 0.22 & 0.42 \\
\hline Dummy for secondary edu. & 0.54 & 0.50 & 0.58 & 0.49 & 0.49 & 0.50 \\
\hline Tenure for last job & 3.48 & 4.49 & 3.92 & 5.12 & 2.86 & 3.35 \\
\hline Married couple with chd & 0.28 & 0.45 & 0.34 & 0.47 & 0.20 & 0.40 \\
\hline Married couple without chd & 0.27 & 0.44 & 0.26 & 0.44 & 0.27 & 0.44 \\
\hline Single parent family & 0.02 & 0.15 & 0.00 & 0.07 & 0.05 & 0.21 \\
\hline Working full time previously & 0.76 & 0.43 & 0.87 & 0.34 & 0.61 & 0.49 \\
\hline Self employed previously & 0.08 & 0.27 & 0.10 & 0.30 & 0.05 & 0.23 \\
\hline Dummy for males & 0.58 & 0.49 & 1.00 & 0.00 & 0.00 & 0.00 \\
\hline Non-Eng. speaking migrant & 0.09 & 0.29 & 0.10 & 0.29 & 0.08 & 0.28 \\
\hline Being retrenched & 0.17 & 0.38 & 0.20 & 0.40 & 0.13 & 0.34 \\
\hline \multicolumn{7}{|l|}{ Industry of previous job: } \\
\hline Agriculture & 0.03 & 0.16 & 0.03 & 0.18 & 0.02 & 0.13 \\
\hline Mining & 0.01 & 0.11 & 0.02 & 0.13 & 0.00 & 0.07 \\
\hline Manufacture & 0.12 & 0.32 & 0.15 & 0.35 & 0.07 & 0.26 \\
\hline Electricity & 0.01 & 0.10 & 0.02 & 0.13 & 0.00 & 0.03 \\
\hline Construction & 0.08 & 0.27 & 0.13 & 0.33 & 0.02 & 0.14 \\
\hline Trade & 0.22 & 0.42 & 0.21 & 0.41 & 0.24 & 0.43 \\
\hline Transport and storage & 0.05 & 0.21 & 0.06 & 0.24 & 0.03 & 0.16 \\
\hline Communication & 0.02 & 0.14 & 0.02 & 0.15 & 0.02 & 0.12 \\
\hline Finance & 0.14 & 0.34 & 0.13 & 0.34 & 0.15 & 0.36 \\
\hline Public Administration & 0.05 & 0.22 & 0.05 & 0.22 & 0.05 & 0.21 \\
\hline Community service & 0.16 & 0.37 & 0.10 & 0.30 & 0.24 & 0.43 \\
\hline Recreation & 0.11 & 0.32 & 0.08 & 0.27 & 0.16 & 0.37 \\
\hline \multicolumn{7}{|l|}{ Region of previous job: } \\
\hline NSW & 0.20 & 0.40 & 0.20 & 0.40 & 0.20 & 0.40 \\
\hline VIC & 0.19 & 0.39 & 0.19 & 0.39 & 0.19 & 0.40 \\
\hline QLD & 0.19 & 0.40 & 0.20 & 0.40 & 0.19 & 0.40 \\
\hline SA & 0.12 & 0.32 & 0.12 & 0.32 & 0.12 & 0.32 \\
\hline WA & 0.14 & 0.35 & 0.15 & 0.36 & 0.13 & 0.34 \\
\hline TAS & 0.05 & 0.23 & 0.05 & 0.23 & 0.05 & 0.23 \\
\hline NT & 0.03 & 0.16 & 0.02 & 0.15 & 0.03 & 0.17 \\
\hline ACT & 0.05 & 0.21 & 0.04 & 0.20 & 0.06 & 0.23 \\
\hline
\end{tabular}




\section{Appendix B: Additional estimation results}

Table B1. Ordered probit estimation of Equation 2 with RANK1 as dependent variable

\begin{tabular}{|c|c|c|c|c|c|c|}
\hline & \multicolumn{2}{|c|}{ Total } & \multicolumn{2}{|c|}{ Males } & \multicolumn{2}{|c|}{ Females } \\
\hline & Coeff. & T-Ratio & Coeff. & T-Ratio & Coeff. & T-Ratio \\
\hline Labour market experience & 0.013 & 2.07 & 0.021 & 2.61 & 0.002 & 0.24 \\
\hline Labour market experience ${ }^{2}$ & 0.000 & -1.00 & 0.000 & -1.47 & 0.000 & 0.02 \\
\hline Age of degree holders & -0.018 & -3.84 & -0.023 & -3.50 & -0.014 & -2.02 \\
\hline Dummy for degree and above & 1.286 & 7.36 & 1.557 & 6.13 & 1.103 & 4.36 \\
\hline Dummy for secondary edu. & 0.166 & 3.06 & 0.250 & 3.40 & 0.055 & 0.66 \\
\hline Technical \& further education & 0.031 & 0.66 & 0.015 & 0.25 & 0.072 & 0.93 \\
\hline Married couple with chd & -0.055 & -1.13 & -0.122 & -1.98 & 0.061 & 0.73 \\
\hline Married couple without chd & -0.061 & -1.32 & -0.096 & -1.51 & -0.026 & -0.37 \\
\hline Single parent family & 0.011 & 0.09 & 0.225 & 0.64 & 0.041 & 0.30 \\
\hline Working full time previously & 0.024 & 0.53 & 0.016 & 0.22 & 0.068 & 1.14 \\
\hline Self employed previously & -0.070 & -1.07 & -0.120 & -1.53 & 0.007 & 0.06 \\
\hline Non-Engl. speaking migrant & 0.001 & 0.02 & 0.005 & 0.06 & -0.005 & -0.06 \\
\hline Dummy for males & -0.137 & -3.48 & & & & \\
\hline Being retrenched & -0.096 & -2.03 & -0.068 & -1.15 & -0.133 & -1.65 \\
\hline Tech-level for previous job & -0.001 & 18.17 & -0.001 & -13.54 & -0.001 & 12.92 \\
\hline \multicolumn{7}{|l|}{ Industry for previous job: } \\
\hline Manufacturing & 0.016 & 0.17 & 0.091 & 0.86 & -0.253 & -1.21 \\
\hline Construction & -0.159 & -1.58 & -0.055 & -0.49 & -0.239 & -0.93 \\
\hline Trade & 0.082 & 0.94 & 0.158 & 1.56 & -0.203 & -1.06 \\
\hline Transport and storage & -0.044 & -0.40 & -0.031 & -0.25 & -0.086 & -0.35 \\
\hline Communication & -0.019 & -0.13 & 0.083 & 0.49 & -0.373 & -1.30 \\
\hline Finance & 0.045 & 0.48 & 0.123 & 1.09 & -0.275 & -1.39 \\
\hline Public administration & 0.136 & 1.19 & 0.221 & 1.62 & -0.155 & -0.68 \\
\hline Community service & -0.022 & -0.24 & 0.059 & 0.50 & -0.286 & -1.46 \\
\hline Recreation & -0.234 & -2.43 & -0.218 & -1.79 & -0.498 & -2.54 \\
\hline \multicolumn{7}{|l|}{ Region for previous job: } \\
\hline NSW & 0.004 & 0.08 & 0.071 & 1.01 & -0.104 & -1.25 \\
\hline QLD & 0.056 & 1.04 & 0.090 & 1.26 & 0.009 & 0.11 \\
\hline SA & 0.028 & 0.45 & 0.090 & 1.09 & -0.056 & -0.57 \\
\hline WA & 0.007 & 0.11 & 0.084 & 1.09 & -0.153 & -1.63 \\
\hline TAS & 0.009 & 0.11 & 0.196 & 1.79 & -0.234 & -1.79 \\
\hline NT & 0.094 & 0.82 & 0.242 & 1.56 & -0.068 & -0.40 \\
\hline $\mathrm{ACT}$ & 0.101 & 1.13 & 0.152 & 1.25 & 0.053 & 0.40 \\
\hline cut 1 & \multicolumn{2}{|c|}{-1.269} & \multicolumn{2}{|c|}{-0.897} & \multicolumn{2}{|c|}{-1.969} \\
\hline $\operatorname{cut} 2$ & \multicolumn{2}{|c|}{0.130} & \multicolumn{2}{|c|}{0.517} & \multicolumn{2}{|c|}{-0.562} \\
\hline Number of observations & \multicolumn{2}{|c|}{4319} & \multicolumn{2}{|c|}{2506} & \multicolumn{2}{|c|}{1813} \\
\hline Pseudo $\mathrm{R}^{2}$ & \multicolumn{2}{|c|}{0.051} & \multicolumn{2}{|c|}{0.054} & \multicolumn{2}{|c|}{0.061} \\
\hline
\end{tabular}


Table B2. OLS estimation with RANK2 as dependent variable

\begin{tabular}{|c|c|c|c|c|c|c|}
\hline & \multicolumn{2}{|c|}{ Total } & \multicolumn{2}{|c|}{ Males } & \multicolumn{2}{|c|}{ Females } \\
\hline & Coeff. & T-Ratio & Coeff. & T-Ratio & Coeff. & T-Ratio \\
\hline Constant & 164.864 & 7.44 & 80.708 & 2.80 & 270.788 & 7.21 \\
\hline Labour market experience & 2.837 & 2.37 & 3.675 & 2.20 & 2.218 & 1.31 \\
\hline Labour market experience $^{2}$ & -0.036 & -1.30 & -0.046 & -1.22 & -0.036 & -0.86 \\
\hline Age of degree holders & -3.522 & -3.86 & -5.098 & -3.75 & -2.777 & -2.33 \\
\hline Dummy for degree and above & 273.762 & 8.06 & 368.418 & 6.98 & 216.248 & 5.04 \\
\hline Dummy for secondary edu. & 41.713 & 3.94 & 64.391 & 4.20 & 12.143 & 0.87 \\
\hline Technical \& further education & 7.607 & 0.83 & 7.266 & 0.58 & 12.485 & 0.95 \\
\hline Married couple with chd & -15.597 & -1.63 & -21.406 & -1.65 & -5.995 & -0.42 \\
\hline Married couple without chd & -14.027 & -1.54 & -15.307 & -1.15 & -15.311 & -1.29 \\
\hline Single parent family & 29.924 & 1.24 & 98.219 & 1.35 & 27.286 & 1.17 \\
\hline Working full time previously & 4.857 & 0.56 & 2.397 & 0.16 & 13.096 & 1.30 \\
\hline Self-employed previously & 5.039 & 0.39 & 6.565 & 0.40 & -1.305 & -0.06 \\
\hline Non-Eng. speaking migrants & 3.384 & 0.28 & 9.487 & 0.57 & -6.351 & -0.38 \\
\hline Dummy for males & -39.983 & -5.18 & & & & \\
\hline Being retrenched & -25.872 & -2.83 & -19.641 & -1.61 & -30.908 & -2.28 \\
\hline Tech-level for previous job & -0.306 & -25.51 & -0.295 & -18.32 & -0.372 & -19.47 \\
\hline \multicolumn{7}{|l|}{ Industry for previous job: } \\
\hline Manufacturing & -7.213 & -0.40 & -9.026 & -0.41 & -4.904 & -0.14 \\
\hline Construction & -37.702 & -1.92 & -28.897 & -1.24 & -17.031 & -0.39 \\
\hline Trade & 10.390 & 0.61 & 15.290 & 0.73 & -8.010 & -0.25 \\
\hline Transport and storage & -27.190 & -1.25 & -30.333 & -1.15 & -10.466 & -0.25 \\
\hline Communication & -0.421 & -0.02 & -12.783 & -0.36 & 22.821 & 0.48 \\
\hline Finance & 27.034 & 1.47 & 34.793 & 1.47 & -3.442 & -0.10 \\
\hline Public administration & 46.927 & 2.11 & 55.034 & 1.94 & 27.178 & 0.71 \\
\hline Community service & 2.090 & 0.11 & 16.687 & 0.68 & -13.274 & -0.41 \\
\hline Recreation & -47.200 & -2.53 & -69.561 & -2.76 & -47.866 & -1.46 \\
\hline \multicolumn{7}{|l|}{ Region for previous job: } \\
\hline NSW & 10.790 & 1.03 & 24.592 & 1.67 & -13.158 & -0.93 \\
\hline QLD & 9.764 & 0.92 & 24.857 & 1.66 & -9.708 & -0.68 \\
\hline SA & 8.142 & 0.66 & 35.999 & 2.08 & -27.803 & -1.67 \\
\hline WA & -12.208 & -1.06 & 9.494 & 0.59 & -51.967 & -3.24 \\
\hline TAS & 5.371 & 0.33 & 47.733 & 2.08 & -47.906 & -2.17 \\
\hline NT & 12.534 & 0.56 & 54.450 & 1.67 & -36.604 & -1.26 \\
\hline $\mathrm{ACT}$ & 30.847 & 1.77 & 75.499 & 2.94 & -18.393 & -0.83 \\
\hline Number of observations & \multicolumn{2}{|c|}{4319} & \multicolumn{2}{|c|}{2506} & \multicolumn{2}{|c|}{1813} \\
\hline Adjusted $\mathbf{R}^{2}$ & \multicolumn{2}{|c|}{0.155} & \multicolumn{2}{|c|}{0.153} & \multicolumn{2}{|c|}{0.192} \\
\hline
\end{tabular}


Table B3 Heckman Sample Selection Model

\begin{tabular}{|c|c|c|}
\hline & Coefficient & T-Ratio \\
\hline Constant & 189.82 & 7.88 \\
\hline Labour market experience & 2.22 & 1.83 \\
\hline Labour market experience 2 & -0.02 & -0.81 \\
\hline Age for degree holders & -3.50 & -3.87 \\
\hline Degree and above qualification & 268.09 & 7.94 \\
\hline Secondary education & 38.42 & 3.64 \\
\hline Technical \& further education & 2.45 & 0.26 \\
\hline Married couple with kids & -15.33 & -1.62 \\
\hline Married couple without kids & -14.08 & -1.56 \\
\hline Single parent family & 30.36 & 1.27 \\
\hline Working full time previously & 2.98 & 0.35 \\
\hline Self-employed previously & 3.00 & 0.24 \\
\hline Non-Eng. speaking migrants & 2.76 & 0.23 \\
\hline Dummy for males & -37.57 & -4.90 \\
\hline Being retrenched & -26.06 & -2.87 \\
\hline Tech-level for previous job & -0.31 & 25.58 \\
\hline Manufacturing & -6.91 & -0.38 \\
\hline \multicolumn{3}{|l|}{ Industrial dummy variables: } \\
\hline Construction & -40.69 & -2.09 \\
\hline Trade & 7.51 & 0.44 \\
\hline Transport and storage & -28.81 & -1.34 \\
\hline Communication & -3.99 & -0.14 \\
\hline Finance & 24.65 & 1.35 \\
\hline Public administration & 44.37 & 2.01 \\
\hline Community service & 0.89 & 0.05 \\
\hline Recreation & -49.04 & -2.64 \\
\hline \multicolumn{3}{|l|}{ Regional dummy variables: } \\
\hline NSW & 8.44 & 0.82 \\
\hline QLD & 7.84 & 0.75 \\
\hline SA & 5.65 & 0.46 \\
\hline WA & -14.05 & -1.23 \\
\hline TAS & 3.64 & 0.23 \\
\hline NT & 10.09 & 0.46 \\
\hline $\mathrm{ACT}$ & 28.87 & 1.68 \\
\hline Lambda & -60.28 & 23.89 \\
\hline Number of observations & 4870 & \\
\hline Model chi2 & 155.07 & \\
\hline
\end{tabular}




\section{References:}

Bartel, A. P. and Sicherman, N., 1999, "Technological change and wages: an interindustry analysis", Journal of Political Economy, 107 (2), 285-325.

Blau, P. M. and Duncan, O. D., 1967, The American Occupational Structure, New York: Wiley.

Borjas, G.J. and S. Rosen, 1980, "Income prospects and job mobility of younger men", Research in Labor Economics, 3, 159-181.

Borland, J., 1994, "Job creation and destruction in Australia in Manufacturing Industry in Australia", Economic Record, 72, 46-62

Boyle, G. and P. McCormack, 2002, "Trade and technological explanations for changes in sectoral labour demand in OECD economies", Applied Economics, 34, 617635.

Brouwer, E., Kleinknecht, A. and Reunen, J., 1993, "Employment growth and innovation at the firm level" Journal of Evolutionary Economics, 3, 153-159.

Callus, R. and Quinlan, M., 1979, “The new unskilled worker”, Journal of Australian Political Economy, 0(6), 74-84.

Chapman, B. J., and Tan, H. W., 1992, “An analysis of youth training in Australia 19851988: Technological change and wages" in R. G. Gregory and T. Karmel (eds.) Youth in the Eighties, Canberra, Centre for Economic Policy Research, Australian National University.

Dao, D., Ross S. and Campbell R., 1993, Structural Change and Economic Growth, AGPS, Canberra.

Davis, S. J., and Haltiwanger, J., 1999, "Gross Job Flows", in Handbook of Labor Economics, vol. 3 B, edited by O.C. Ashenfelter and D. Card, Elsevier, Amsterdam.

De Wit, G. R., 1990, "A review of the literature on technological change and employment", MERIT, University of Limburg.

Dickens, W. T. and Katz, K. F., 1987, "Inter-industry wage differences and industry characteristics", in Kevin Lang and Jonathan Leonard (eds.) Unemployment and the Structure of Labor Markets, New York: Basil Blackwell.

Dunne, T. and Schmitz, Jr. J. A., 1995, "Wages employment structure and employer size-wage premia: their relationship to advanced-technology usage at U.S. manufacturing establishments", Economica, 62, 89-107. 
Entorf, H. and Kramarz, F., 1998, "The impact of new technologies on wages: lessons from matching panels on employees and on their firms" Economics of Innovation and New Technology, 5 (2-4), pp. 165-97.

Evans, P. (1999) “Occupational Downgrading and Upgrading in Britain”, Economica, 66, 79-96.

Farber, H.S., 1999, "Gross Job Flows", in Handbook of Labor Economics, vol. 3 B, edited by O.C. Ashenfelter and D. Card, Elsevier, Amsterdam.

Florida, R. (2002), The Rise of the Creative Class, New York: Basic Books.

Fox, K.J., 2002, "Measuring technical progress in matching models of the labour market", Applied Economics, 34, 741-748.

Goldin, C. and Katz, L., 1996, "The origins of technology-skill complementarity" NBER Working Paper 5657.

Gordon, D. M., 1986, "Procedure for allocating jobs in labor segments" The New School for Social Research, New York.

Griliches, Z., 1969, "Capital-skill complementarity", Review of Economics and Statistics, 51, 465-468.

Hauser, R. M. and Featherman, D. L., 1977, The Process of Stratification: Trends and Analyses, New York: Academic Press.

Jones, F., 1989, "Occupational prestige in Australia: a new scale", Australian and New Zealand Journal of Sociology, 25(2), 187-199.

Jovanovic, B. 1979, Job Matching and the Theory of the Theory of Turnover, Journal of Political Economy, 87, 972 - 990.

Jovanovic, B., and Nyarko, Y., 1995, "The transfer of human capital", Journal of Economic Dynamics and Control, 19, 1033-1064

Junankar, P. N., Kapuscinski, C. A., and Meng, X., 1996, "Labour mobility in Australia in the nineties: a preliminary look at the effects of technological change", Paper presented at the $25^{\text {th }}$ conference of Economists, Australian National University, Canberra, 23-25 September, 1996.

Kaplinsky, R., 1987, "Micro-electronics and employment revisited: A review", ILO, Geneva.

Kilpatrick, S. and Felmingham, B, 1996, "Labour mobility in the Australian regions" Economic Record, 72(218), 214-223.

Krueger, A. B., 1993, "How computers have changed the wage structure: evidence from microdata, 1984-1989” Quarterly Journal of Economics, 108, 33-60. 
McDonald, J.T. and B.S. Felmingham (1999) "Voluntary and involuntary labour mobility of Australian men over the business cycle", Australian Bulletin of Labour, 25 (2), 141-158.

Meyer-Krahmer, F., 1992, "The effects of new technologies on employment", Economics of Innovation and Technological change, vol. 2.

Mincer, J., 1958. "Investment in Human Capital and Personal Income Distribution", Journal of Political Economy. 66 (4), 281-302.

Mincer, J., 1991, "Human capital, technology and the wage structure: what do the series show?", NBER Working Paper No. 3581.

Najman, J. M. and Bampton, M., 1991, "An ASCO based occupational status hierarchy for Australia: a research note" Australian and New Zealand Journal of Sociology, 27(2), 218-231.

Nelson, R. R. and Phelps, E. S., 1966, "Investment in humans, technological diffusion, and economic growth", American Economic Review, 56, 69-75.

Northcott, J., 1984, Micro-Electronics in British Industry: The Pattern of Change, Policy Studies Institute London.

OECD, 1994, The OECD Jobs Study, Paris: Head of Publications Service, OECD.

Romer, D.,1996, Advanced Macroeconomics, New York, McGraw Hill.

Sicherman, N. and O. Galor, (1990) “A theory of job mobility', Journal of Political Economy, 98 (1), 169-192.

Slifman, L., 1976, "Job mobility and labor demand" Industrial Relations, 15(2), 147157.

Topel, R. H., 1994, "Regional labor markets and the determinants of wage inequality", American Economic Review, 84, 17-22.

Waddoups, J., Daneshvary, N., and Assane, D., 1995, “An analysis of occupational upgrading differentials between black and white males" Applied Economics, 27(3), 841-847.

Williams, L.S., 1980, A Two-Stage Approach to the Modelling of Inter-occupational Mobility in Australia, Australian Economic Papers, 19, 147-154. 


\section{Appendix C: Structural change of employment in Australia}

Over the last 10 years the Australian economy has experienced profound structural change as a result of technological change, changes in consumers' tastes, and microeconomic reform. This had a great impact upon the industrial structure of employment. Figure $\mathrm{C} 1$ presents the annual net change of employment by industries for the period 19851995. The overall picture for the last decade suggests that agriculture, mining, and electricity, gas and water are the industries which are losing employment. In contrast, finance, recreation, community service, wholesale and retail trade, and construction are the large growth industries. This structural change, however, varies over the business cycle. When the economy was declining (1990-1993), apart from the recreation, community services, and public service sectors, all industries were employment losers. However, when the economy started to grow (1993-1995), most industries gained employment. Employment in the communication, manufacturing and construction, in particular, fluctuated dramatically with the movement of the economic cycle.

Figure C1. Average annual changes in employment by industry

1985-1995 (\%)

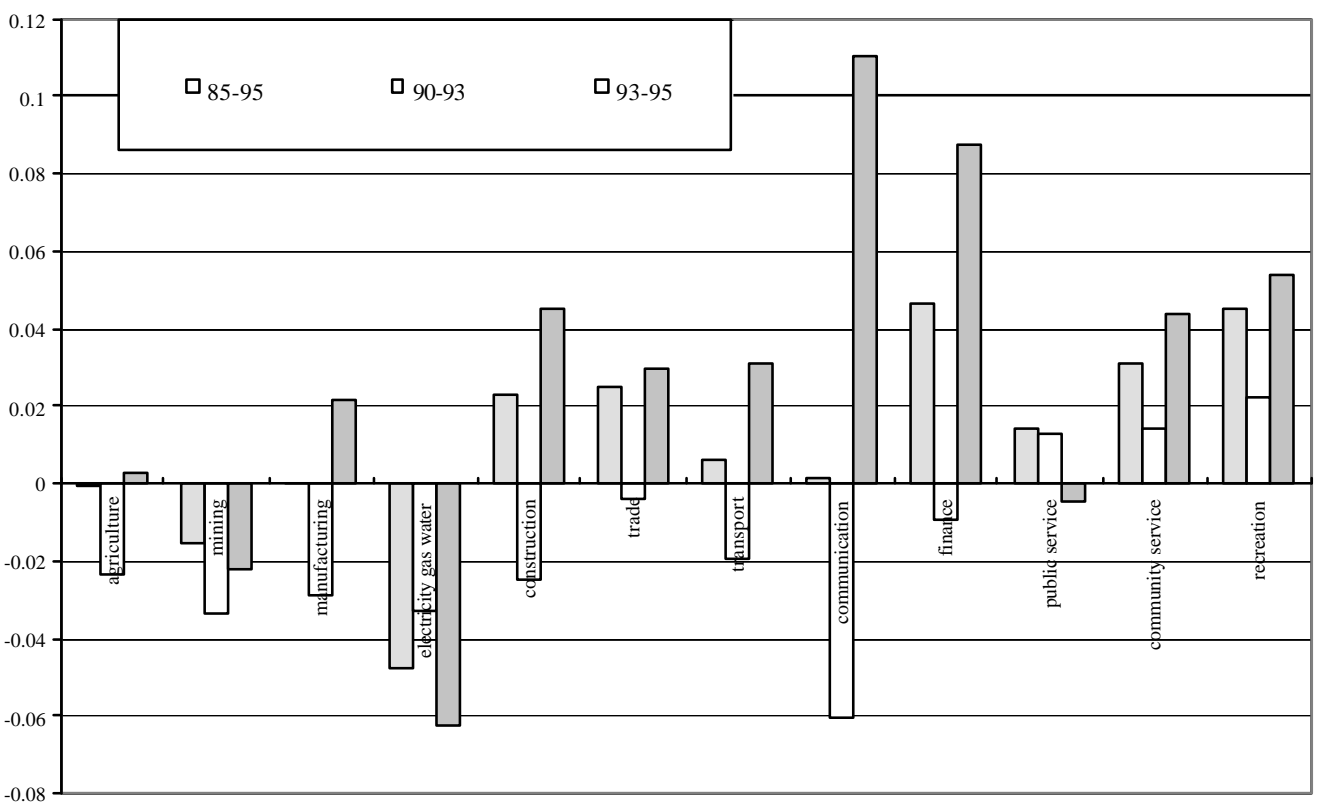

Source: ABS time series data, DX, 1996. 
As one might expect, the sectors which gained in employment terms are not necessarily the high-tech industries, nor do low-tech industries always constitute the sectors which lost employment. Following on from this observation, Table $\mathrm{C} 1$ presents a comparison between the technological ranking and employment-gaining ranking for the 12 sectors in the Australian economy (as defined by 1-digit ASIC classification). The technological level ${ }^{20}$ in the table is proxied by the percentage of highly educated employees and the percentage of employees who use a computer at work. ${ }^{21}$,

Table $\mathrm{C} 1$ and Figure $\mathrm{C} 2$ present a mixed picture with two of the relatively high-tech industries (electricity and mining) being employment losers and three of the relatively lowtech industries (construction, trade and recreation) being major employment gainers. The situation of losing employment in the mining and electricity industries is basically due to the fact that the final demand effect is smaller than the labour saving effect. More specifically, this situation may be pinned down to the following factors. First of all, the development of these two relatively high-tech sectors is constrained by limited access to natural-resources. Second, under this constraint, if technological change accelerates, the original less-skilled labour force will be crowded out by capital- or skill-intensive technology. For example, over the last decade, the capital/labour ratio in the mining industry increased by 6.4 per cent per annum compared to a 1 per cent per annum decrease in the whole economy. On the other hand, the three identified low-tech employment-gaining sectors are either cyclically sensitive or with apparently high income elasticities. ${ }^{22}$

Table C1. Comparison between technological ranking and employment gaining ranking: ASIC 1 digit sectors ${ }^{\mathrm{a}}$

\begin{tabular}{|c|c|c|c|c|c|}
\hline & $\begin{array}{l}\% \text { of highly } \\
\text { educated }^{\mathrm{b}}\end{array}$ & $\begin{array}{l}\% \text { of employees } \\
\text { using computer }^{\mathrm{c}}\end{array}$ & $\begin{array}{c}\text { ranking for } \\
\text { highly educated }\end{array}$ & $\begin{array}{c}\text { ranking for } \\
\text { computer usage }\end{array}$ & $\begin{array}{c}\text { Employment } \\
\text { gaining ranking } \\
\end{array}$ \\
\hline Construction & 2.8 & 40.1 & 1 & 2 & 8 \\
\hline Agriculture & 3.2 & 32.3 & 2 & 1 & 3 \\
\hline Transport & 3.8 & 58.4 & 3 & 5 & 6 \\
\hline Trade & 4.4 & 61.2 & 4 & 6 & 9 \\
\hline Manufacturing & 5.3 & 49.8 & 5 & 3 & 4 \\
\hline Recreation & 6.2 & 54.8 & 6 & 4 & 11 \\
\hline
\end{tabular}

\footnotetext{
${ }^{20}$ See Section 2 for a detailed discussion of the problems of defining the technological level of a job.

${ }^{21}$ The percentage of highly educated employees is defined as a ratio of the number of employees with a degree or above to the total number of employees.

${ }^{22}$ However, when reading Table 1, one should bear in mind that although the employment gain ranking is a dynamic picture of the changing trend, the technology ranking presented in the table is only a snapshot of the current situation. It does not take into account the change in the technology level of the individual sectors.
} 


\begin{tabular}{l|ccccc}
\hline \hline Communication & 6.5 & 79.1 & 7 & 10 & 5 \\
Electricity, gas, water & 7.9 & 71.1 & 8 & 9 & 1 \\
Mining & 8.9 & 63.6 & 9 & 7 & 2 \\
Finance & 18.4 & 83.4 & 10 & 12 & 12 \\
Public service & 18.8 & 80.4 & 11 & 11 & 7 \\
Community service & 29.2 & 70.1 & 12 & 8 & 10 \\
\hline \hline
\end{tabular}

Source: ABS 1991 Census, ABS 1993 Training and Education Experience Survey.

Note: a. The ranking in this table is ascending, that is 1 refers to the lowest rank and 12 refers to the highest rank.

b. The percentage of highly educated employee is calculated from ABS 1991 Census data. Here, employees with degree and above is defined as highly educated.

c. Data for the percentage of employees who use a computer at work are obtained from the ABS 1993 Training and Education Experience Survey.

d. Employment gains ranking is over the period of 1985-1995. It is ranked according to the data presented in Figure C1.

Figure C2 Ranking of technological level and employment gaining

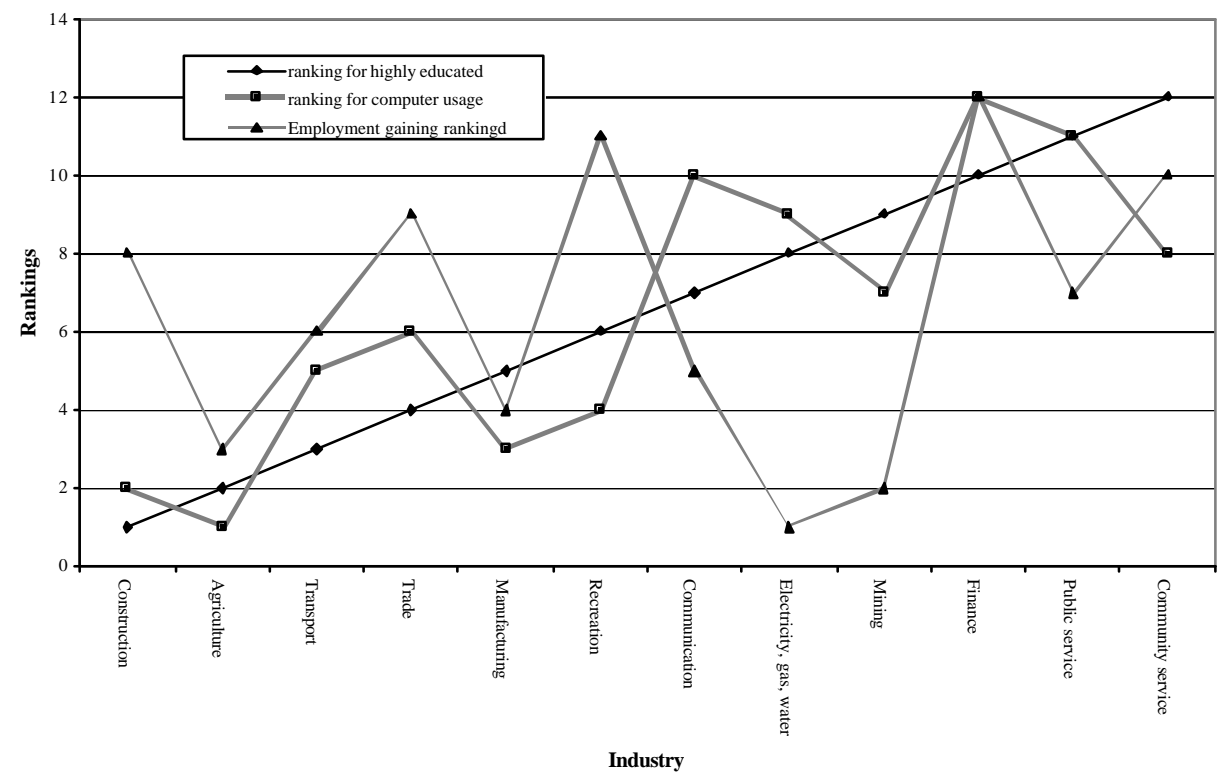

Source: Data obtained from Table C1.

To sum up, the Australian economy has experienced considerable structural change, whereby the output and technology level in each sector has changed. As a result, the structure of employment is also affected. The dynamic process of this change is evidenced by individuals' job mobility across industries, occupations and even geographic regions. To understand the aggregated impact of technological change on employment, a thorough analysis of the trend of individuals' job mobility along the technological ladder is necessary. 


\section{Appendix D: Who moves along the technological ladder in Australia?}

The basic statistical description of the data presented here provides a crude picture of who moved jobs and where they went in terms of movement along the technological ladder. However, the factors affecting job mobility along the technological ladder may work in different ways and directions. Thus, these results should be considered in conjunction with the multivariate results presented in the paper.

In order to assess who moved up or down the technological ladder, Table D1 shows some characteristics of employees for each category. On average, people who moved jobs within the original industry-occupation cells are older, more experienced, with higher qualifications, are more likely to be a full-time worker previously and are less likely to be retrenched in comparison to those who moved across industries or occupations.

When comparing the other two categories, it is found that people who moved down the technological ladder are younger, but have longer potential work experience than those who moved up the ladder. However, this pattern differs between men and women. On average, women moving down the technological ladder are slightly older and more experienced than those who moved up the ladder. There is a higher percentage of individuals with a degree or higher qualification who moved up the ladder than those who moved down the ladder (18 per cent and 13 per cent, respectively). This is more so for women than for men. On the other hand, of individuals who were retrenched from the last job more moved down the ladder than moved up the ladder. Other variables, such as marriage or full-time position for the previous job, do not seem to affect the direction of movement along the technological ladder. 
Table D1. Average characteristics of individuals by movement on technological ladder

\begin{tabular}{|c|c|c|c|c|c|c|}
\hline & \multicolumn{2}{|c|}{ Total } & \multicolumn{2}{|c|}{ Men } & \multicolumn{2}{|c|}{ Women } \\
\hline & Mean & S.D. & Mean & S.D. & Mean & S.D. \\
\hline \multicolumn{7}{|l|}{ Age } \\
\hline Down & 30.96 & 10.53 & 31.86 & 10.86 & 29.79 & 9.96 \\
\hline Stable & 34.13 & 10.59 & 35.13 & 10.59 & 32.72 & 10.42 \\
\hline Up & 31.08 & 10.09 & 32.17 & 10.29 & 29.51 & 9.60 \\
\hline Total & 32.53 & 10.56 & 33.54 & 10.69 & 31.13 & 10.21 \\
\hline \multicolumn{7}{|c|}{ Tenure in the last job } \\
\hline Down & 3.48 & 4.49 & 3.92 & 5.12 & 2.86 & 3.35 \\
\hline Stable & 3.30 & 4.62 & 3.79 & 5.39 & 2.67 & 3.28 \\
\hline Up & 3.54 & 4.23 & 3.91 & 4.69 & 3.02 & 3.42 \\
\hline Total & 3.53 & 4.83 & 4.08 & 5.60 & 2.76 & 3.30 \\
\hline \multicolumn{7}{|c|}{ Potential experience } \\
\hline Down & 14.18 & 10.75 & 15.06 & 10.93 & 13.03 & 10.41 \\
\hline Stable & 16.71 & 11.01 & 17.50 & 10.92 & 15.60 & 11.04 \\
\hline Up & 14.01 & 10.63 & 15.18 & 10.73 & 12.34 & 10.25 \\
\hline Total & 15.37 & 10.92 & 16.29 & 10.94 & 14.09 & 10.78 \\
\hline \multicolumn{7}{|c|}{ Degree and above } \\
\hline Down & 0.13 & 0.33 & 0.11 & 0.31 & 0.15 & 0.36 \\
\hline Stable & 0.22 & 0.41 & 0.18 & 0.39 & 0.26 & 0.44 \\
\hline Up & 0.18 & 0.38 & 0.14 & 0.35 & 0.23 & 0.42 \\
\hline Total & 0.18 & 0.39 & 0.15 & 0.36 & 0.22 & 0.42 \\
\hline \multicolumn{7}{|c|}{ Secondary } \\
\hline Down & 0.56 & 0.50 & 0.57 & 0.50 & 0.54 & 0.50 \\
\hline Stable & 0.53 & 0.50 & 0.59 & 0.49 & 0.45 & 0.50 \\
\hline Up & 0.54 & 0.50 & 0.56 & 0.50 & 0.50 & 0.50 \\
\hline Total & 0.54 & 0.50 & 0.58 & 0.49 & 0.49 & 0.50 \\
\hline \multicolumn{7}{|c|}{ Being retrenched } \\
\hline Down & 0.24 & 0.43 & 0.27 & 0.44 & 0.20 & 0.40 \\
\hline Stable & 0.10 & 0.30 & 0.12 & 0.33 & 0.07 & 0.26 \\
\hline Up & 0.24 & 0.42 & 0.28 & 0.45 & 0.18 & 0.38 \\
\hline Total & 0.17 & 0.38 & 0.20 & 0.40 & 0.13 & 0.34 \\
\hline \multicolumn{7}{|c|}{ Married } \\
\hline Down & 0.51 & 0.50 & 0.56 & 0.50 & 0.45 & 0.50 \\
\hline Stable & 0.62 & 0.49 & 0.67 & 0.47 & 0.55 & 0.50 \\
\hline Up & 0.50 & 0.50 & 0.55 & 0.50 & 0.44 & 0.50 \\
\hline Total & 0.56 & 0.50 & 0.61 & 0.49 & 0.50 & 0.50 \\
\hline \multicolumn{7}{|c|}{ Full time in last job } \\
\hline Down & 0.70 & 0.46 & 0.82 & 0.39 & 0.56 & 0.50 \\
\hline Stable & 0.81 & 0.39 & 0.92 & 0.27 & 0.65 & 0.48 \\
\hline Up & 0.72 & 0.45 & 0.83 & 0.38 & 0.57 & 0.50 \\
\hline Total & 0.76 & 0.43 & 0.87 & 0.34 & 0.61 & 0.49 \\
\hline
\end{tabular}

Source: Authors' calculation.

An investigation of previous industry affiliation and occupation provides some insight into individuals' prospective job mobility paths from different industries and occupations. Tables D2 and D3 present the percentage of individuals moving up or down the technological ladder within each industry and occupation, respectively. Data from Table D2 
suggest that a larger proportion of individuals in the finance and recreation industries moved down the technological ladder than those who moved up. In contrast, a greater percentage of people in the construction, manufacturing, mining, and electricity industries moved up the ladder than those who moved down.

Further, Table D3 suggests that people who were originally in a high-ranking occupation (i.e. managerial or professional) are more likely to move down the ladder compared to people who are in a low-ranking occupation (i.e. labourers or machinery operators). This, however, is more likely to be due to the impact of the initial condition of employment.

Table D2. Job mobility along the technology ladder by industry affiliation of the previous job (\%)

\begin{tabular}{l|cccc}
\hline \hline & $\begin{array}{c}\text { Down } \\
(\mathbf{1})\end{array}$ & Stable (2) & $\begin{array}{c}\text { Up } \\
\mathbf{( 3 )}\end{array}$ & $\mathbf{( 3 ) - ( 1 )}$ \\
\hline Agriculture & 30.36 & 35.71 & 33.93 & 3.57 \\
Mining & 27.27 & 32.73 & 40.00 & 12.73 \\
Manufacturing & 26.51 & 37.15 & 36.35 & 9.84 \\
Electricity, gas, water & 17.78 & 48.89 & 33.33 & 15.55 \\
Construction & 14.49 & 56.82 & 28.69 & 14.20 \\
Wholesale/retail trade & 24.56 & 45.10 & 30.34 & 5.78 \\
Transport and storage & 17.48 & 55.34 & 27.18 & 9.70 \\
Communication & 23.86 & 52.27 & 23.86 & 0.00 \\
Finance & 26.51 & 56.54 & 16.95 & -9.56 \\
Public administration & 28.11 & 47.00 & 24.88 & -3.23 \\
Community service & 22.77 & 57.23 & 20.00 & -2.77 \\
Recreation & 37.50 & 41.94 & 20.56 & -16.94 \\
Total & 25.38 & 48.65 & 25.98 & 0.60 \\
\hline \hline
\end{tabular}

Source: Authors' calculation.

Table D3. Job mobility along the technology ladder by occupation (\%)

\begin{tabular}{l|cccc}
\hline \hline & Down & Stable & $\mathbf{U p}$ & $\mathbf{( 3 ) - ( 1 )}$ \\
& $(\mathbf{1})$ & $\mathbf{( 2 )}$ & $\mathbf{( 3 )}$ & \\
\hline Managers & 25.76 & 52.08 & 22.16 & -3.60 \\
Professional & 26.53 & 61.78 & 11.69 & -14.84 \\
Para-professional & 12.60 & 67.32 & 20.08 & 7.48 \\
Tradesperson & 11.29 & 56.76 & 31.95 & 20.66 \\
Clerk & 29.01 & 44.13 & 26.86 & -2.15 \\
Salesperson & 31.60 & 44.97 & 23.43 & -8.17 \\
Machinery operators & 16.00 & 45.82 & 38.18 & 22.18 \\
Labourers & 32.75 & 32.75 & 34.50 & 1.75 \\
Total & 24.47 & 50.02 & 25.50 & 1.03 \\
\hline \hline
\end{tabular}

Source: Authors' calculation. 